\title{
Beyond Quantitative and Qualitative Traits Three Telling Cases in the Life Sciences
}

\author{
- Pre-print Version - \\ Davide Serpico \\ Department of Classics, Philosophy and History \\ University of Genoa \\ Published in Biology \& Philosophy \\ https://doi.org/10.1007/s10539-020-09750-6
}

Keywords: Quantitative Traits; Qualitative Traits; Mendelian Diseases; Genetic Liability; Thresholds; Character States.

\begin{abstract}
This paper challenges the common assumption that some phenotypic traits are quantitative while others are qualitative. The distinction between these two kinds of traits is widely influential in biological and biomedical research as well as in scientific education and communication. This is probably due to both historical and epistemological reasons. However, the quantitative/qualitative distinction involves a variety of simplifications on the genetic causes of phenotypic variability and on the development of complex traits. Here, I examine three cases from the life sciences that show inconsistencies in the distinction: Mendelian traits (dwarfism and pigmentation in plant and animal models), Mendelian diseases (phenylketonuria), and polygenic mental disorders (schizophrenia). I show that these traits can be framed both quantitatively and qualitatively depending, for instance, on the methods through which they are investigated and on specific epistemic purposes (e.g., clinical diagnosis versus causal explanation). This suggests that the received view of quantitative and qualitative traits has a limited heuristic power-limited to some local contexts or to the specific methodologies adopted. Throughout the paper, I provide directions for framing phenotypes beyond the quantitative/qualitative distinction. I conclude by pointing at the necessity of developing a principled characterisation of what phenotypic traits, in general, are.
\end{abstract}




\section{Introduction}

Genetics textbooks often draw a distinction between two types of phenotypic traits: on the one hand, quantitative traits, also labelled as 'complex' or 'polygenic,' among which height, skin colour, and intelligence are three renowned examples; on the other hand, qualitative traits, often described as 'simple' or 'monogenic,' among which prominent examples are pea seeds colour and Mendelian diseases.

The distinction between quantitative and qualitative traits is influential in scientific education, communication, and research across biological and biomedical sciences. This popularity is probably due to both historical and epistemological reasons. From a historical point of view, the distinction relates to the classical separation of biometrical and Mendelian theories of heredity, which strongly resonates in contemporary scientific practices. In epistemological terms, instead, the concepts of quantitative and qualitative traits seem to be understood as conceptually clear descriptions of phenotypes with a great heuristic and methodological potential. In this sense, the two concepts seem to be consistently associated, respectively, with a variety of aspects of organismal biology and its study, including: continuous and discontinuous phenotypic variations; polygenic and monogenic inheritance patterns; complex and simple genotype-phenotype (G-P) maps; quantitative and qualitative methodologies.

In this paper, I challenge the assumption that the quant/qual distinction is, in fact, consistent, which is the basis to think that it can serve as a useful heuristic for biological and biomedical research. I discuss specific cases from Mendelian, biomedical, and behavioural genetics that illustrate inconsistencies in the distinction and its applications. Thus, I provide directions for framing phenotypic traits alternatively. Here below is the structure of the paper.

In Section 2, I outline the received view of quantitative and qualitative traits as typically described in genetics textbooks and discuss some possible reasons of the popularity of the distinction in genetics research.

In Section 3, I analyse qualitative traits by focusing on three Mendelian traits: dwarfism, pigmentation, and phenylketonuria. Through the analysis of these cases, I show that the concept of qualitative traits leads researchers to take the association between single-gene variations and phenotypic variations as the basis for a definitional approach of phenotypes. Notably, this approach represents a major source of misconceptions of genetics findings among non-specialists. In order to illustrate 
misunderstandings connected with the notion of qualitative trait, I shall consider (an adapted version of) the distinction between characters and characters states.

In Section 4, I turn to the concept of quantitative traits by examining the case of mental disorders - in particular, schizophrenia - which can be framed either qualitatively or quantitatively depending on the theoretical model assumed: the quantitative-liability model is an attempt to fit schizophrenia in the standard definition of quantitative trait; by contrast, the threshold model frames schizophrenia through a mixed qualitative-quantitative conceptual strategy. I argue that the purely quantitative characterisation of schizophrenia is afflicted by remarkable theoretical difficulties (the distinction between characters and character states will be of central importance here, too). Thus, I turn to the threshold model as a plausible way out from the quant/qual distinction in the psychiatric context. Before concluding, I will outline what conceptual tools the concept of threshold could introduce, more generally, in the analysis of complex traits.

In conclusion, I highlight that the problems identified throughout the paper are conceptual in nature and concern the way we think of the relationship between the genotype and the phenotype. This points at the necessity to provide a principled characterisation of what phenotypic traits, in general, are.

\section{The Received View of Quantitative and Qualitative Traits}

The distinction between quantitative and qualitative traits dates back to the early twentieth century, when scholars were working to establish the basis of modern genetics. Back then, researchers mostly framed phenotypes according to two general approaches, namely, biometrics and Mendelism, which were concerned with the study of quantitative and qualitative inheritance, respectively. The biometrical approach originated from the late work of Francis Galton (e.g., 1894) and was characterised by the study of heredity through statistical methods-e.g., the analysis of correlations among relatives-developed by Galton himself and his intellectual descendants, e.g., Pearson, Weldon, and Yule. The Mendelian approach to heredity, in turn, was largely based on the analysis of pure lines developed by Gregor Mendel (1866) and the following Mendelians, e.g., Bateson, DeVries, Johannsen, and Punnet 
(see Griffiths \& Stotz, 2013; Norton, 1975; Provine, 1971; Schwartz, 2009; Visscher \& Goddard, 2018). ${ }^{1}$

The work of biometricians was mostly focused on traits that vary continuously in populations such as height, skin colour, and intelligence. For these traits, all values or gradations within a certain range can be observed (Mather, 1941, p. 160). For instance, different values of height or different scores in Intelligent Quotient (IQ) tests can be ordered on a single dimension so that phenotypes gradually 'shade' one into the other-to put it simply, it makes little sense to say that there are just 'tall' and 'short' people.

Ever since the biometrical school identified nature and nurture as the two main sources of variation in quantitative traits, scholars assumed that the development of these traits is due to many factors, including several independent genes (up to hundreds or thousands, that additively influence the phenotype) and environmental influences. The involvement of many genetic and environmental effects of small magnitude would explain why phenotypes vary continuously in populations (see Fisher, 1918; Fisher et al., 1932; Dobzhansky, 1970; Mather, 1941, 1943, 1964).

Notably, according to the polygenic model, no gene in a polygenic system is individually necessary. So, two individuals can have the same phenotype with different allelic makeups (Pierce, 2017). For instance, two individuals can be equally tall (e.g., $168 \mathrm{~cm}$ ) due to different allelic combinations. This is well expressed by the following mathematical description, which, for the sake of simplicity, considers the genotype at just three loci:

"With only three polygenes of equal effect, the genotypes AABBcc, AAbbCC and aaBBCC will, for example, give the same phenotype. This phenotype would also characterize the genotypes AaBBcc, AABbcc, AaBbcc, etc., if dominance were the rule, or AABbCc, AaBBCc, and AaBbCC in the absence of dominance. [...] The allelomorphs designated by small letters are assumed to add nothing to the expression of the character, while each allelomorph designated by a capital letter adds 1 unit. [...] As the number of genes involved increases, more phenotypes are possible, and the distribution becomes more nearly continuous [...] as observed, for example, in human stature" (Mather, 1943, pp. 39-40). ${ }^{2}$

Due to the small individual effect of each allele, the action of genes on quantitative traits is to be studied en masse via statistical methods (Griffing, 1950, p. 303).

\footnotetext{
${ }^{1}$ This standard reconstruction is, however, historically inaccurate (see Footnote \#8).

${ }^{2}$ Note that this idealised explanation represents a standard one in quantitative genetics (e.g., Pierce, 2017; Purcell, 2013).
} 
Thus, the study of these traits has mostly involved the variance-partitioning approach and heritability analyses, thanks to which researchers have investigated the relative magnitude of genetic and environmental influences on a trait's variation (see Downes \& Matthews, 2019; Visscher et al., 2008). ${ }^{3}$ More recently, genome-wide association studies (GWAS) have allowed identifying the statistical association between genotypic and phenotypic variation in quantitative traits (see Downes \& Matthews, 2019; Eley \& Rijsdijk, 2005).

Let us now turn to qualitative traits. These traits are often called 'binary', 'yes/no', or 'either-or' traits because they fit into discrete categories, e.g., the yellow or green colour of pea seeds (Falconer \& MacKay, 1996; Knopik et al., 2017; Pierce, 2017; Plomin et al., 2013; Purcell, 2013). Traits of this sort are often regarded as controlled by single genes (Ahluwalia, 2009). ${ }^{4}$ Rare human pathologies such as phenylketonuria, Huntington Chorea, and cystic fibrosis are famous for being associated with single genetic variants and, thus, are usually called Mendelian diseases. ${ }^{5}$

On the methodological side, molecular methods such as the candidate-gene approach derive from this classical Mendelian framework. The assumption, here, is that it is promising to seek the specific genes causing qualitative traits (or single alleles associated with a trait's variation) because their individual effect is appreciable at the phenotypic level-technically, such genes are highly penetrant on the phenotype. Due to the strong penetrance of single genetic variants in qualitative traits, the importance of environmental factors on these traits is thought to be small:

"Genes can influence phenotypes through major biochemical pathways [strong genetic explanations]. This is the case with monogenic diseases and conditions that involve a small number of genes" (DarNimrod \& Heine, 2011, p. 5).

"[In] the traits that Mendel studied, as well as [in] Huntington disease and PKU, [...] a single gene is necessary and sufficient to cause the disorder. That is, you will have Huntington disease only if you have the $H$ allele (necessary); if you have the $H$ allele, you will have Huntington disease (sufficient). Other genes and environmental factors have little effect on its inheritance" (Knopik et al., 2017, p. 32; see also Plomin et al., 2013, p. 32, pp. 94-95).

\footnotetext{
${ }^{3}$ For some critical discussions on nature/nurture and heritability analyses, see Block (1995); Lewontin (1974); Tabery (2014).

${ }^{4}$ Mather $(1941,1943)$ originally called "oligogenic" the inheritance pattern characterising these traits and defined it as involving one or a few genes. However, over time, the term 'oligogenic' became ambiguous and almost synonymic with 'monogenic' (see, e.g., Katsanis, 2016).

${ }^{5}$ For a comprehensive database of Mendelian traits, see https://omim.org (Accessed 18 August 2019). See also https://www.who.int/genomics/public/geneticdiseases/en/index2.html (Accessed 19 July 2019).
} 
"For some discontinuous characteristics, the relation between genotype and phenotype is straightforward: each genotype produces a single phenotype, and most phenotypes are encoded by a single genotype. Dominance and epistasis may allow different genotypes to produce the same phenotype, but the relation remains simple" (Pierce, 2017, ch. 24).

Some of the descriptions above might sound a bit oversimplifying. And, indeed, they are. For instance, the idea that the development of qualitative traits is controlled by single genes and that environmental influences have little-if any-role seems to overlook the complexity of biological systems-note, for instance, that a trait's expression can be modulated by genetic, epigenetic, and environmental interactions, even in Mendelian diseases (Brooker, 2018; Chen et al., 2016; Cooper et al., 2013; Hartl \& Jones, 1998; Hartwell et al., 2018; Jang, 2005; Katsanis, 2016; Strachan $\&$ Read, 2011). Moreover, although variation in Mendelian traits usually relates to single-gene variations, such traits are apparently anything but 'simple.' These aspects have attracted many criticisms as they connect, for instance, to genetic determinism, genetic essentialism, and simplistic G-P mapping (Burian \& Kampourakis, 2013; Dar-Nimrod \& Heine, 2011; Kendler, 2005; Jamieson \& Radick, 2013; Ratner, 2004; I will return to these problems in Section 3).

The description of quantitative traits, on the other hand, seems to be much more 'realistic.' However, many scholars have raised doubts about the suitability of the classical polygenic model to account for phenotypic development. Indeed, the model is mostly aimed at describing statistical properties of populations like variance and heritability and endorses a variety of idealisations on genes' functioning, e.g., additivity and equality of genetic effects (see Carlborg \& Haley, 2004; Gottlieb, 1995; Lewontin, 1974; Nelson et al., 2013; Turkheimer, 2011). Furthermore, the quantitative framework seems to be better suited to describe traits that vary on a single, monotonic dimension (like height) and less suited to account for traits like intelligence and mental disorders (I will return to these problems in Section 4).

Despite these reasonable concerns, the separation between quantitative and qualitative approaches to the study of phenotypes is widely influential. In the next section, I will show that the distinction is not limited to genetics textbooks but extends to scientific research as well. 


\subsection{Evidence of the Popularity of the Distinction}

The separation between quantitative and qualitative approaches to the study of phenotypes is particularly evident in genetics textbooks, where the quant/qual distinction is frequently cited to compare and explain Mendelian and quantitative genetics (e.g., Ahluwalia, 2009; Brooker, 2018; Falconer \& MacKay, 1996; Hartl \& Jones, 1998; Hartwell et al., 2018; Klug et al., 2016; Knopik et al., 2017; Pierce, 2017; Strachan \& Read, 2011). Since it is possible that simplifications have been introduced in textbooks for pedagogical reasons, one may wonder whether the quant/qual distinction plays any role beyond education.

To evaluate this, I conducted a bibliometric research on the database of Web of Science (WoS) (see Appendix). The results suggest that the concepts of quantitative and qualitative trait are ubiquitous across biological and biomedical sciences $(37,715$ publications cite quantitative traits and characters; 3,233 publications cite qualitative or Mendelian traits, characters, and diseases), with no sign that their importance has decreased over time (see Appendix: Query \#1-3). Moreover, the number of publications citing the two terms together is much smaller than the number of publications that investigate only one of the two (only 418 publications cite the two terms together; see Appendix: Query \#4). This suggests that the separation between the two domains of inquiry is real and strong.

This bibliometric research is not to be taken as a comprehensive account of the use of the quant/qual distinction in the literature. One limitation is that the WoS' Advanced Search tool limits investigation to titles, keywords, and abstracts; this potentially includes irrelevant literature and excludes some relevant publications. ${ }^{6}$

For instance, the impressive difference in size between the datasets on quantitative and qualitative traits does not necessarily mean that qualitative traits are of little importance in the life sciences: this can well be a merely linguistic bias. Indeed, most research on qualitative traits employs terms such as 'discrete trait/character,' 'qualitative inheritance,' or just the name of the trait under examination (e.g., 'cystic fibrosis,' 'Huntington Chorea,' and 'phenylketonuria'). This is testified by the fact that the number of results increases if terms such as 'Mendelian trait/character/disease' are included in the query (see Appendix: Query \#3). Notably, genetics textbooks

\footnotetext{
${ }^{6}$ However, these limitations are uniform across the searched titles; so, the research should not present any biases when examining trends in the use of the terms over time or across research areas.
} 
often use terms other than 'trait' as well (e.g., Brooker, 2018; Hartl \& Jones, 1998; Hartwell et al., 2018; Klug et al., 2016; Strachan \& Read; 2011). ${ }^{7}$

Another limitation of this bibliometric research is that a simple terminological investigation is unable to uncover the reasons why the two terms are employed. In the next section, I suggest that the popularity of the two concepts can depend on both historical and epistemological reasons.

\subsection{Potential Reasons for the Popularity of the Distinction}

Part of the influence of the quant/qual distinction might be due to the historical separation of biometrical and Mendelian theories of heredity, with their different methodological and theoretical focus, which resonates in contemporary science-this is testified, for instance, by the small number of publications investigating quantitative and qualitative traits together (see above). In the early twentieth century, biometrical and Mendelian approaches seemed to be incompatible with each other due to their different epistemological and metaphysical stances on a variety of topics. Authors from the two sides disagreed, for instance, on how to characterise the G-P relationship, what genes are, and how evolutionary processes occur (see Ahluwalia, 2009; Griffiths \& Stotz, 2013; Mather \& Jinks, 1982; Norton, 1975; Provine, 1971; Radick, 2005, 2011; Visscher \& Goddard, 2018). Eventually, however, the two theories revealed to be compatible with each other and were unified into a single theoretical model, namely, contemporary quantitative genetics. Scholars who worked on this unification proposed that complex traits are influenced by several alleles, each of which is inherited according to Mendelian laws. ${ }^{8}$

\footnotetext{
${ }^{7}$ Note that, although most biological characteristics are thought to be quantitative, much more attention in genetics textbooks is given to Mendelian traits-the analysis of quantitative genetics is usually confined to a chapter towards the end of the book (e.g., Hartl \& Jones, 1998; Pierce, 2017; Snustad \& Simmons, 2012).

8 The unification of biometrics and Mendelism is usually attributed to Fisher's 1918 infinitesimal model (e.g., Morrison, 2007; Plomin et al., 2013; Visscher \& Goddard, 2018). However, well before Fisher, scholars from both sides achieved similar results or proposed ways for bridging the gap between the two, including East (1910), Johannsen (1903), Nilsson-Ehle (1909), Pearson (1900), Tammes (1911), Yule (1902), but also Mendel himself as well as Weldon in unpublished works (see Cock, 1973; Jamieson \& Radick, 2013; Müller-Wille \& Richmond, 2016; Porter, 2005; Radick, 2005; Roll-Hansen, 1978; Stamhuis, 1995). I thank Staffan Müller-Wille (personal communication, January 2017) and Ida H. Stamhuis (July 2019) for pointing at these works.
} 
From this synthesis, a sort of consensus originated about the existence of both quantitative and qualitative traits: accordingly, quantitative traits represent the norm (most biological characteristics are, in this sense, biometrical) but some traits (mostly rare diseases) are due to 'simple' Mendelian patterns or determined by single genes.

From an epistemological point of view, the popularity of the quant/qual distinction can be due to its apparent simplicity and putative heuristic power. Indeed, the distinction seems to represent a good way to easily grasp a variety of properties associated with the two types of traits, including: continuous versus discontinuous phenotypic variations; polygenic versus monogenic inheritance patterns; complex versus simple G-P maps; and quantitative versus qualitative methodologies. These aspects of organismal biology and its study seem to be consistently associated with quantitative and qualitative traits, respectively, and this would be a good reason for adopting the quant/qual distinction.

My critical target is the assumption that the distinction is, in fact, consistent. In order to clarify the point, let me introduce a hypothetical account of quantitative and qualitative traits that sharply separates quantitative and qualitative aspects. Based on the received view summarised in Section 2, such an account can be outlined as follows (see also Table 1):

1) Population variation: In any given population, some traits are normally distributed while others give rise to discrete and mutually exclusive categories. In the case of continuous variation, individuals display the trait 'in different degrees' (e.g., stature and IQ). In the case of discontinuous variation, instead, individuals display the trait or not (e.g., presence/absence of a disease) or are characterised by different forms of the trait (e.g., yellow/green colour).

2) Inheritance patterns: The observed patterns of how phenotypic traits pass from parents to offspring can be polygenic or monogenic. While polygenic inheritance characterises traits that are inherited in accordance with quantitative genetics principles (e.g., Galton's regression), monogenic inheritance concerns traits inherited in accordance with Mendelian laws (e.g., traits can be dominant or recessive).

3) Genotype-phenotype relationship: The G-P map (say, the genetic architecture and developmental pathways of biological characteristics) can be either 'complex' or 
'simple.' In this view, complex traits develop under the influence of many genetic and environmental effects. By contrast, Mendelian traits are due to the influence of single, highly penetrant genes, and thus environmental effects are negligible for these traits.

4) Methodologies: Different methodologies are traditionally associated with the analysis of quantitative and qualitative traits. Statistical and biometrical methods (e.g., the analysis of variance, heritability, and GWAS) identify statistical regularities, similarities, and differences between contiguous generations or between populations. These methods are better suited to analyse polygenic inheritance and the source of continuous variation in natural populations. By contrast, Mendelian methods are better suited for the study of traits where the G-P map is 'simple' and where population variation is discontinuous. Among them is the analysis of pure lines-which is usually adopted in experimental contexts where it is possible to control for the environment and other developmental variables-but also later acquisitions such as linkage analyses, the candidate-gene approach, and gene knockout experiments.

\begin{tabular}{ccccc}
\hline & $\begin{array}{c}\text { Population } \\
\text { Variation }\end{array}$ & $\begin{array}{c}\text { Inheritance } \\
\text { Patterns }\end{array}$ & $\begin{array}{c}\text { Genotype- } \\
\text { Phenotype Map }\end{array}$ & Methodologies \\
\hline $\begin{array}{c}\text { Qualitative Traits } \\
\text { Mendelian Traits }\end{array}$ & Discontinuous & $\begin{array}{c}\text { Monogenic } \\
\text { Mendelian }\end{array}$ & Simple & Experimental \\
\hline $\begin{array}{c}\text { Quantitative } \\
\text { Traits }\end{array}$ & Continuous & Polygenic & Complex & $\begin{array}{c}\text { Statistical } \\
\text { Biometrical Traits }\end{array}$ \\
\hline
\end{tabular}

Table 1: A hypothetical account of quantitative and qualitative traits, based on the received views. The account sharply separates quantitative and qualitative aspects of organismal biology and its study.

In this account, quantitative and qualitative aspects and methodologies are clearly disentangled from each other. However, there are important exceptions that cast doubts on the suitability of the quant/qual distinction, particularly on its heuristic power and ability to account for the G-P relationship. For instance, many traits that vary discontinuously in populations are not necessarily influenced by single 
genes-rather, they can involve complex G-P maps. Furthermore, the very same trait can vary continuously in some circumstances and discontinuously in others.

In the next two sections, I will consider inconsistencies in the quant/qual distinction through the analysis of three cases: Mendelian traits (dwarfism and pigmentation), Mendelian diseases (phenylketonuria), and polygenic mental disorders (schizophrenia). I will show that these traits can be framed both quantitatively and qualitatively depending, for instance, on the methods through which they are investigated, as well as on factors such as epistemic purposes (e.g., clinical diagnosis versus causal explanation). This implies that the quant/qual distinction has, at best, a limited heuristic power-limited to some local contexts or to the specific methodologies adopted.

\section{Beyond Qualitative Traits: The Telling Case of Mendelian Traits}

Most biological characteristics are thought to be quantitative or 'complex.' In this view, many genetic and environmental influences are involved in the development of such traits, and this makes sense of why phenotypes of most biological characteristics are normally distributed. At the same time, we know that individual differences in complex traits can be categorical or discontinuous in some circumstances, e.g., in cases where single genetic variants cause phenotypic abnormalities. This leads many to believe that some traits are, in fact, qualitative. How can the same trait vary continuously or discontinuously in different circumstances? As I will explain, the question itself depends on mistaking Mendelian methods as a guide to provide definitional criteria of phenotypic traits.

\subsection{The Cases of Dwarfism and Pigmentation in Plant and Animal Models}

Height is usually considered a quantitative trait across the animal and plant kingdom, which means that it varies continuously in populations and there is no single gene 'for' height. However, in some circumstances, height can vary discontinuously. This happened, for instance, in Mendel's classical study of pea plants (Mendel, 1866). 
"One of the characteristics studied by Mendel was the height of pea plants, which can be described by measuring the length of a plant's stem. However, Mendel's particular plants exhibited only two distinct phenotypes (some were tall and others short), and these differences were determined by alleles at a single locus. The differences that Mendel studied were therefore discontinuous in nature" (Pierce, 2017, ch. 24).

Essentially, the problem lies in the fact that traits that can be measured on a continuous scale do not always exhibit continuous variation. A fruitful way to clarify this is considering Mather's explanation of this phenomenon:

"It is possible that, if some organism could be grown in a constant environment and rendered homozygous for all but one of the genes affecting a quantitative character, this one gene might be observed to segregate and give sharply distinct classes just as a qualitative gene does. [...] Stature, for example, is usually a quantitative character, but in many organisms, dwarf forms are known to segregate sharply from the normal type, so falling into the qualitative class" (Mather, 1941, p. 160).

The circumstances Mather refers to are basically those in which all individuals in a population are exposed to equal (or similar enough) environmental conditions and are genetically identical (or similar enough) to each other but for one gene. In these circumstances, variation at one locus makes a difference at the level of phenotypic variation in a population. ${ }^{9}$ These circumstances are, for instance, those required to identify genetic mutations in the analysis of pure lines. Here, researchers are interested in the differential action of genes, that is, the effects of single genetic variants while other variables are held constant. This approach characterised, for instance, Thomas Morgan's research on Drosophila melanogaster in the 1910s:

"Morgan and his school were well aware that, as a rule, many genes were involved in the development of a particular trait as, e.g., eye-color, and that one gene could affect several characters. [...] What mattered to them was the relationship between a change in a gene and a change in a trait, rather than the nature of these entities themselves. Thus the alteration of a trait could be causally related to a change in (or a loss of) a single genetic factor, even if it was plausible in general that a trait like eyecolor was, in fact, determined by a whole group of variously interacting genes" (Rheinberger et al., 2015).

Research has revealed that eye colour in Drosophila is due to two separate biochemical pathways producing brown and red pigments, respectively. Moreover,

\footnotetext{
${ }^{9}$ On the concept of genetic difference-maker and other definitions of genetic causality, see Burian \& Kampourakis (2013), DiFrisco \& Jaeger (forthcoming), Griffiths \& Stotz (2013), Lynch (under review), Okasha (2009), Waters (2007).
} 
pigments bind to a granule in the pigment cell of the eye. Failure of this binding process, or disruptions in the biochemical pathways that produce pigments, result in the lack of pigment regardless of the pigments produced (see Pollock, 1989). Notably, when variation in a trait depends on single-gene mutations, the trait appears to have a simple, linear correlation to one gene (read: a simple G-P map) as long as other developmental elements remain constant. However, this does not imply that the trait is monogenic or 'simple' in developmental terms: what is simple, if anything, is the separation between two classes of phenotypes, e.g., 'normal' and 'abnormal' height or different colours. Thus, contra the received view of qualitative traits, traits that can vary discontinuously in populations can still develop under the influence of many genetic and environmental effects. ${ }^{10}$

Early geneticists (e.g., Morgan et al., 1915) were aware that the natural development of, for instance, pigmentation is due to many genes-each of which, we now know, encodes a specific enzyme that enters a biochemical cascade producing the observed colour. However, eventually, this causal explanation was simplified to the point that a simple G-P map (one gene-one trait) was inferred from Mendelian studies (see, e.g., DiFrisco \& Jaeger, 2019; Rheinberger et al., 2015). Simplifications of this sort are especially evident in scientific education and communication, where discourses about the gene 'for' $x$ (where $x$ is any complex trait) are rampant (see Burian \& Kampourakis, 2013; Jamieson \& Radick, 2013; Kendler, 2005; Ratner, 2004).

Importantly, the concept of qualitative trait both reflects and perpetuates the simplifications above. In the next section, I focus on Mendelian diseases as other problematic cases for the quant/qual distinction and provide directions for thinking beyond the concept of qualitative trait.

\subsection{The Case of Phenylketonuria}

Traits like cystic fibrosis and Huntington Chorea are usually regarded as qualitative traits insofar as they are influenced by single genes. This simple G-P relationship has been translated into praxis as a diffuse definitional approach that takes the empirical association between genotypic and phenotypic variation to identify phenotypic

\footnotetext{
${ }^{10}$ Note, for instance, that many traits that have been long considered Mendelian or monogenic, like eye and hair colour, have proved to be polygenic (see McDonald, 2012; Sturm \& Frudakis, 2004).
} 
traits themselves. The case of phenylketonuria (PKU), a widely studied metabolic disorder, is particularly telling about the impossibility of defining phenotypes that way.

Phenylalanine is an amino acid contained in many types of food which is part of our everyday diet. In the human body, phenylalanine is metabolised by an enzyme called phenylalanine hydroxylase, which mostly exerts its function in the liver. In individuals affected by PKU, the enzyme is incapable of converting phenylalanine into tyrosine, so phenylalanine assumed through diet is stockpiled in blood and brain. This can result in various neurodevelopmental issues, including severe cognitive disability. Genetically, PKU is associated to mutations in the PAH gene, which is located on the twelfth chromosome (an individual must carry two recessive $P A H$ alleles to manifest the clinical condition).

PKU seems to fit well into the standard definition of qualitative trait. Indeed, any population can be divided into two categories: healthy and affected individuals. In developmental terms, since PKU is due to mutations in a single gene, the G-P map is fairly simple, and this leads to the assumption that mutations in the $P A H$ gene are necessary and sufficient conditions for being affected by the disease (e.g., Knopik et al., 2017; Plomin et al., 2013).

There are two major problems with this popular characterisation of PKU. The first problem concerns the simplified view of the G-P map it offers (see Section 3.1). The second problem regards the usual definitional criteria adopted for Mendelian diseases. Let us see them one by one.

It is well known that it is possible to prevent the PKU's clinical onset by adopting a diet poor of phenylalanine early in childhood. This means that phenylalanine intake and a mutation in the PAH gene are both necessary for developing PKU; thus, it would be more accurate to say that mutations in the $P A H$ gene are necessary but not individually sufficient (see Kempthorne, 1978). But the story does not end there: genetic mutations involved in Mendelian diseases are not always completely penetrant, that is, an individual can harbour such mutations but not develop symptoms (Chen et al., 2016; Cooper et al., 2013; Katsanis, 2016; Lynch, under review). Note, for instance, that researchers have identified about 500 different $P A H$ mutations associated with PKU, with different phenotypic effects (Plomin et al., 2013; Scriver, 2007). This makes it even harder to make claims about necessary and sufficient conditions of qualitative traits or to say that their inheritance pattern is 'simple.'

Let us turn to the second problem. The definition of PKU as a trait in general (and a qualitative one, specifically) draws on the association between the disease 
and single-gene mutations. Thus, essentially, PKU is taken as a qualitative trait insofar as it relates to a well-defined genotypic characteristic. However, it is worth asking: is PKU a trait at all?

To address the question (and to clarify its very purpose), let me introduce the distinction between characters and character states (or simply states, hereafter). These two terms are frequently mentioned in the literature on homology as regards questions on morphological development across different taxa (see DiFrisco, 2019; Colless, 1985; Wagner, 2014).11 Notably, the use of the two terms in biology is not at all consistent (for some reviews, see Colless, 1985; Freudenstein, 2005; Fristrup, 2001).

In my discussion, characters represent general, species-specific phenotypic characteristics, e.g., height, skin colour, and intelligence in humans. On the other hand, character states are determinate properties or values of those characters that vary between the members of a species (either continuously or discontinuously) and, thus, characterise individual organisms, e.g., dwarfism, a specific height value, a specific skin colour, cognitive disability, or a specific IQ score. In other words, characters come in different forms or states in different individuals of a given species. ${ }^{12}$

I shall suggest that PKU would be better understood as a character state, rather than a character, specifically a state of the character 'liver metabolism.' Accordingly, there is a variety of possible states of liver metabolism, each of which characterises different individuals; PKU is one of such states, particularly one that involves the inability of metabolising phenylalanine due to malfunctioning of the enzyme phenylalanine hydroxylase. Strictly speaking, mutations in the $P A H$ gene cause problems in the structure and function of such enzyme, driving liver metabolism towards the PKU state. By contrast, the development of the general liver metabolism (the character) is not just caused by one gene: rather, several genetic and environmental influences are involved in the development of liver metabolism. Thus, PKU represents a condition in which an abrupt disruption of normal development occurs. In this sense, PKU, rather than a trait stricto sensu, represents a variant form (a state) of the normal liver metabolism.

\footnotetext{
${ }^{11}$ I thank James DiFrisco for pointing at this literature (personal communication, August 2018).

${ }^{12}$ In metaphysical terms, characters and states can be considered determinables and determinates, respectively (on this distinction, see Wilson, 2017). For instance, 'red eye' and 'brown eye' are determinates of the determinable 'eye colour.'
} 
The characters/states distinction aims to stress that the development of characters like height, intelligence, and physiological systems usually relates to many interacting genetic and environmental influences; by contrast, character states can sometimes causally depend on just one genetic difference-maker, as in the case of Mendelian diseases like PKU. ${ }^{13}$ Thus, defining phenotypic traits on the basis of single-gene mutations-and taking PKU, for instance, as a character-can misrepresent how biological systems (and complex systems in general) work.

To make the point clearer, let us consider the laptop on which I am now typing. The laptop is made of a high number of components that are designed and interconnected to generate my everyday experience with the device. The internal organisation of the laptop is complex enough to prevent significant changes in its behaviour due to a small malfunctioning in its hardware. However, some malfunctioning can have disruptive effects on my laptop. For instance, malfunctioning in the hard drive will put my machine in serious danger, and I may experience a variety of issues, e.g., errors in the information visualised on the display, errors in the files system, internet connection issues, and so forth. If a malfunctioning in the hardware is associated with, for instance, malfunctioning in the music player, e.g., crackling audio, one might be tempted to describe the malfunctioning itself (the crackling audio) as a 'trait' of the laptop and to identify the single defective hardware component as the major 'developmental cause' of the trait. This, however, would be a serious misunderstanding.

A component that generates an error in the laptop's behaviour is not necessarily what causes the laptop's behaviour in normal conditions: it can be that the defective component makes a difference in the behaviour of the laptop by causing major disruptions in the system. However, the normal behaviour of the laptop is due

\footnotetext{
${ }^{13}$ Note that my definition of characters and states is consistent with Lawrence's (2008) but departs from that of scholars working on homology. For instance, according to Wagner, "the relationship between character identity and character states is the same as that for gene identity and alleles in genetics" (2014, pp. 53-54). This seems to imply that there is a one-to-one relationship between, for instance, the alleles $a, b$ and $c$ of the gene $x$ and the relative states $a^{*}, b^{*}$, and $c^{*}$ of the character $x^{*}$. However, in my definition, the relationship between a gene and its possible alleles (at the genotypic level) and a character and its possible states (at the phenotypic level) is just analogical and should not be understood in causal terms. Indeed, different states of the same character can have different types of developmental causes. For instance, the state $a^{*}$ can be due to just one difference-maker, but the state $b^{*}$ can be influenced by many genes or involve environmental influences. Moreover, the developmental causes of a character can differ greatly from those of its states. For example, the character 'eye colour' in flies develops under the influences of many genes, but the state 'red eye' can depend on just one genetic difference-maker. In other words, the species-specific development of a trait on the one hand, and the development of specific variants of such trait on the other, can be due to (partly) different developmental causes.
} 
to its many interacting components, which all are necessary for the proper functioning of the machine. Conceptually, as regards the trait's identification, the abnormal behaviour of the laptop would be better regarded as one possible state of the laptop's behaviour, rather than a trait.

To return to biology, mutations in an individual's genotype can make a difference to a variety of observable characteristics of the organism. In PKU, for instance, mutations in the $P A H$ gene can affect the liver's functioning and lead to neurodevelopmental issues and cognitive disability. However, the mutated $P A H$ gene does not cause a trait (and, a fortiori, not a qualitative one). Rather, it drives a biological system towards one of the possible states of the liver metabolism character.

To summarise, analysing phenotypic variation and the G-P map along the lines above reveals that the concept of qualitative trait is far more ambiguous (and, therefore, less heuristically useful) than usually acknowledged. Moreover, the concept of qualitative trait can lead us to take the association between single-gene variations and phenotypic variations as guidance to identify traits themselves-it is in this definitional approach that probably lies a major source of oversimplified, popular descriptions of genetics findings in scientific education and communication (see Section 3.1). However, in developmental terms, what we often call 'qualitative traits' are not even traits: they are states of far more complex polygenic traits (not necessarily quantitative, though; see Section 5).

In the next section, I will discuss the concept of quantitative traits by analysing the case of polygenic mental disorders-specifically, schizophrenia-and argue that this concept, when applied to behavioural phenotypes, invites equivocations as well.

\section{Beyond Quantitative Traits: The Telling Case of Mental Disorders}

The general idea behind the notion of quantitative trait is that individuals differ from each other quantitatively in terms of a single, monotonic dimension. For instance, an individual's skin pigmentation can be described as a point in a mono-dimensional space. Likewise, individuals vary in height on a single dimension that can be measured in centimetres or inches. This characterisation might sound unproblematic for physical traits like height but, in the case of behavioural traits, it is. Traits like intelligence and mental disorders are unlikely reducible to a single dimension: rather, 
they involve several properties at different levels of organisation that are qualitatively distinct from each other. ${ }^{14}$

For the sake of the discussion, I will leave aside the problem of how to define schizophrenia and mental disorders more generally. ${ }^{15} \mathrm{My}$ central aim is to show that the concept of quantitative trait seems unable to account for complex traits that vary discontinuously in populations. Mental disorders, for instance, are often considered yes/no traits because "disorders are diagnosed as either-or dichotomies" (Plomin et al., 2013, p. 88), but they arguably are anything but simple or monogenic. Recently, researchers have made the case that all mental disorders might be, in fact, inherently quantitative (see Plomin et al., 2009).

In this section, I take schizophrenia as a case study to assess whether mental disorders fit in the standard definition of quantitative trait. I will argue that this is not the case and that schizophrenia is better characterised by the so-called threshold model. In this view, neither purely quantitative nor purely qualitative explanatory strategies seem to work here. These complications testify that, in the behavioural domain, the quant/qual distinction loses its clarity and does not represent a practical and powerful heuristic tool.

\subsection{The Case of Schizophrenia}

The DSM's definitional approach is well-known to be symptoms-based and categorical in nature: several signs and symptoms are associated with a given clinical picture, and diagnosis only occurs if an individual presents a minimum number of such symptoms (APA, 2013; Jang, 2005). In DSM-5, for instance, schizophrenia's diagnostic criteria include two or more symptoms among delusions, hallucinations,

\footnotetext{
${ }^{14}$ For instance, at the behavioural level, IQ represents a single dimension on which all individuals can be placed. However, this dimension does not correspond to a single cognitive or biological phenomenon: rather, the behavioural generality of intelligence is realised by the interaction between many cognitive and neurobiological processes, e.g., working memory, processing speed, reasoning, metacognition, and neural plasticity, as well as linguistic, mathematical, and visuospatial abilities (see Kovacs \& Conway, 2016; Kray \& Frensch, 2002; Serpico, 2018; Van der Maas et al., 2006).

${ }^{15}$ Here, I refer to the definition of schizophrenia adopted in contemporary psychiatric nosography (i.e., the one usually cited by behavioural geneticists), which is mostly based on the Diagnostic and Statistical Manual of Mental Disorders (DSM), now at its fifth edition (APA, 2013).
} 
disorganised speech, disorganised or catatonic behaviour, and negative symptoms - at least one of the first three must be observed (APA, 2013, p. 99). ${ }^{16}$

Thus, in terms of phenotypic variation, schizophrenia tends to vary discontinuously in populations: broadly speaking, individuals can be affected by the disorder or not. As Nick Haslam notices,

"Existing psychiatric classifications generally represent mental disorders as discrete [...] categories, and diagnoses are made in a dichotomous, present-or-absent fashion" (Haslam, 2014, p. 15).17

Nevertheless, no one would say that disorders like schizophrenia are 'simple' in the sense of the definition of qualitative traits: indeed, the development of such traits (as well as their variation) is widely thought to be due to multiple genetic and environmental effects. To hold together the etiological complexity of mental disorders with the (at least apparent) 'simplicity' of their phenotypic variability, behavioural geneticists have proposed two main theoretical models: first, the quantitative-liability model, which frames them in a purely quantitative way; second, the threshold model, which conceptualises disorders through a sort of mixed quantitative-qualitative strategy. ${ }^{18}$

These two models share the assumption that genetic risk factors are normally distributed and introduce a variable called liability to which underlying risk factors would contribute (Falconer, 1965; Snustad \& Simmons, 2012, p. 610). In accordance with the polygenic model of complex traits (see Section 2), some alleles are thought to increase the risk of developing a given disorder. For instance, in Knopik and colleagues' words,

"Theoretically, there should be a continuum of genetic risk, from people having none of the alleles that increase risk for schizophrenia to those having most of the alleles that increase risk. Most people should fall between these extremes, with only a moderate susceptibility to schizophrenia" (Knopik et al., 2017, p. 36).

\footnotetext{
${ }^{16}$ Diagnostic criteria for schizophrenia involve other aspects concerning, e.g., the level of social functioning and the persistence of symptoms over time. These aspects are not relevant to my discussion.

${ }^{17}$ Note that, although diagnosis remains categorical, the latest edition of DSM includes a sort of 'spectrum' of psychotic disorders, where some conditions are characterised by fewer (or less severe) symptoms than major disorders (APA, 2013, p. 122; see also Fusar-Poli et al., 2013). I thank Valentina Petrolini for pointing at this literature (personal communication, January 2020). About categorical versus dimensional approaches in psychiatry, see Keil et al. (2017).

${ }^{18}$ While the name 'threshold model' is somewhat standard, 'quantitative-liability model' is of my choice.
} 
The two models mostly differ in how they conceptualise another concept they introduce, that is, the concept of threshold. This concept is intuitively described as a point where the underlying genetic risk produces, like an on/off button, a discontinuous variation. However, threshold is admittedly a hypothetical construct that needs further investigations (Burton et al., 2007; Falconer, 1965; Knopik et al., 2017). The differing way the two models conceptualise thresholds is important for our discussion as it makes the difference between a purely quantitative and a nonquantitative account of traits like schizophrenia. In the next two sections, I will analyse these two theoretical models in detail.

\subsection{The Quantitative-liability Model}

According to the quantitative-liability model, symptoms of mental disorders increase continuously from normality to abnormality, and disorders denote conditions that are conventionally separated from normality due to pragmatic concerns. For instance, the threshold can be drawn on the basis of the number of symptoms, like in the case of DSM's cut-offs, or of their clinical significance (Jang, 2005). According to Knopik and colleagues, this is straightforward for traits like depression:

"People vary in the frequency and severity of their depression. Some people rarely get the blues; for others, depression completely disrupts their lives. Individuals diagnosed as depressed might be extreme cases that differ quantitatively, not qualitatively, from the rest of the population" (Knopik et al., 2017, p. 37).

Even for disorders like schizophrenia, the authors say, there may be no sharp line dividing the normal from the abnormal, but rather a continuum from normality to abnormality (Knopik et al., 2017, pp. 36-37; Plomin et al., 2009).

Notably, a "certain level of symptom severity" is not to be taken as a point where the accumulation of risk-factors produces a 'real' qualitative change in the system. In other words, in the quantitative-liability model (in contrast to the threshold model, see Section 4.3), thresholds do not represent 'natural' or 'internal' discontinuities. ${ }^{19}$ So, the biology of schizophrenic individuals is thought to be quantitatively

${ }^{19}$ On this view, mental disorders would correspond to so-called practical kinds (see Haslam 2014; Zachar, 2000). 
different from the biology of healthy ones, rather than qualitatively, and discontinuous variation in schizophrenia is just 'apparent.'

A way for understanding this model is to conceive of liability as a measure of how penetrant the genotype is on the phenotype, that is, of how much underlying genetic risk becomes visible at the phenotypic level-all other developmental elements being equal. In some individuals, the number of 'pathological alleles' is high enough to generate clinically significant symptoms, so that diagnosis occurs. By contrast, in healthy individuals, the number of 'pathological alleles' is too small to make symptoms clinically relevant or even detectable, but symptoms are, in a sense, always there. ${ }^{20}$ This implies that we all are affected by schizophrenia, but to a different degree: we just differ to each other in terms of how penetrant the 'schizophrenic genotype' is on our phenotype and on how much symptoms impact our lives.

According to the advocates of the quantitative-liability model, schizophrenia fits in the standard definition of quantitative trait. For instance, Plomin and colleagues (2009) argue that the model involves a radical shift in focus from a qualitative to a quantitative framework of mental disorders:

"These quantitative traits need not be limited to symptoms of the diagnosed disorder but can occur at any level of analysis. [...] Once multiple genes are found to be associated with a disorder, understanding the mechanisms by which each gene affects the disorder leads to quantitative traits being recognized at all levels of analysis: from gene expression profiles, to other '-omic' levels of analysis, to physiology and often to the structure and function of the brain" (Plomin et al., 2009, p. 874).

Although this model might sound attractive for the supporters of a dimensional characterisation of mental disorders, it presents two conceptual problems that raise doubts on this particular interpretation of quantitative traits: first, the assumption that genetic risk is normally distributed is essentially based on the observation of symptoms; second, the model identifies mental disorders with characters, while they probably are character states. Let us analyse these problems one by one.

The first problem concerns the fact that the assumption of a continuum between normality and pathology at the genotypic level draws on the continuum observed at the phenotypic level: symptoms have degrees of severity, and such severity is understood as a function of the number of 'pathological alleles' (those that bring about

\footnotetext{
${ }^{20}$ Note that the model assumes that there is a frequency distribution for the severity of every symptom, and each person displays all symptoms to some degree (Jang, 2005, p. 47).
} 
negative effects at the phenotypic level, see Section 2). In this sense, the model offers a somewhat linear view of the G-P map.

In part, this view is inherited by classical models in quantitative genetics (Fisher, 1918; Mather, 1943), where linearity was a mathematical idealisation (see DiFrisco \& Jaeger, 2019; Nelson et al., 2013; Zhu et al., 2009). This view, however, is also based on the assumption that observed symptoms represent useful starting points to make hypotheses on the genetic basis of mental disorders. This somehow contrasts with recent trends in psychiatric research. For instance, the NIHM Research Domain Criteria framework (RDoC) reflects a trend in research aimed at unpacking classical symptoms-based clinical pictures to identify their multiple cognitive and emotional components, with an eye on the social determinants of disorders, too. As Insel explains,

“So far, we don't have rigorously tested, reproducible, clinically actionable biomarkers for any psychiatric disorder. Genetic findings are statistical associations of risk, not diagnostic of disease; neuroimaging findings report mean group changes, not individual differences; and metabolic findings are not specific. We can improve the resolution with each of these modalities, but we may never have a biomarker for any symptom-based diagnosis because these diagnostic categories were never designed for biological validity" (Insel, 2014, p. 395).

The popularity of the RDoC's approach among philosophers and theorists of psychiatry testifies a general distrust for models that make claims on the biology of mental disorders on the basis of observable symptoms. As far as this applies to the quantitative-liability model of schizophrenia, a continuum in symptoms' severity does not necessarily imply that schizophrenia is a quantitative trait, nor that we all are schizophrenic 'to different degrees.'

A second problem with the quantitative-liability model is that it conceptualises disorders as characters. As I mentioned, the model holds that we all are affected by mental disorders like depression and schizophrenia: while for some of us symptoms are not clinically significant, so they are for others. This implies that schizophrenia is essentially comparable to other species-specific traits like height, skin colour, and intelligence, which are shared by all human beings-we all are tall to a certain degree, we all have pigmentated skin cells, we all are 'intelligent.'

However, as in the case of PKU examined in Section 3.2, schizophrenia is unlikely a species-specific character; rather, it is a character state, that is, a variant form of a character. But what character? Classical research on the neurobiology of schizophrenia attributes its typical symptoms to a disturbed and hyperactive 
dopaminergic signal transduction, but other studies have pointed at the involvement of the glutaminergic system and of malfunctioning in gliogenesis (see Coyle, 2006; Dietz et al., 2020; Insel, 2010; Kendler, 2014). Regardless of what hypothesis will turn out to be empirically correct, the characters/states distinction suggests framing schizophrenia as one possible state of the functioning of the human neuroendocrine-metabolic system. ${ }^{21}$

This implies, contra the quantitative-liability model, that schizophrenia is not a trait that all humans have 'to different degrees.' Rather, all humans have a neuroendocrine system that produces neuropeptides in response to both internal and external stimuli; the functioning of this system can vary from person to person and from time to time and, for some individuals at specific points in time, the system's functioning produces clinically relevant symptoms associated with the clinical picture described in DSM.

In sum, the quantitative-liability model, as an account of the genetics of schizophrenia, is conceptually problematic: on the one hand, the multiple dimensions hypothesised are merely symptomatic in nature; on the other, the model misinterprets mental disorders as characters. If my arguments are sound, the attempt to provide a purely quantitative description of schizophrenia is just as problematic as the attempt to provide a purely qualitative description of Mendelian diseases (analysed in Section 3.2).

In the next section, I will discuss the threshold model of schizophrenia, according to which this disorder can be reduced neither to the standard definition of quantitative traits nor to that of qualitative trait. This suggests that, at least in the case of schizophrenia, the quant/qual distinction is not heuristically powerful as it is intended to be.

\subsection{The Threshold Model: A Promising Way Out?}

The threshold model and the quantitative-liability model of schizophrenia share the view that genetic risk-factors are normally distributed. However, the threshold model conceives of thresholds as sorts of 'internal discontinuities' or 'switch-points'

\footnotetext{
${ }^{21}$ It is well possible that more than one schizophrenia state will be identified, each of which associated with its own typical symptoms, biomarkers, and aetiologies. This would not represent an obstacle for my proposal to conceive of schizophrenia(s) as a state(s) instead of a character(s).
} 
where the accumulation of such factors brings about a mental disorder (Pierce, 2017; Plomin et al., 2013). Thus, thresholds are conceived of as 'genuine' features of biological systems, rather than something that is just conventionally placed.

Metaphorically, thresholds can be understood as 'on/off buttons.' On/off states, then, would represent two qualitatively different states of a biological system, which correspond to the presence or absence of schizophrenia. This implies that the biology of schizophrenic individuals is qualitatively different from the biology of healthy ones, rather than just quantitatively.

Note that this characterisation of schizophrenia is not reducible to the standard definitions of quantitative or qualitative traits: on the one hand, schizophrenia is not a quantitative trait because the pathological state is described as qualitatively different from the healthy one(s); on the other hand, schizophrenia is not a qualitative trait because, albeit it can vary discontinuously in populations, it is complex and polygenic.

The hypothesis that mental disorders like schizophrenia are threshold traits is not new (e.g., Plomin et al., 2013). However, in contrast to the concept of quantitative liability, the concept of threshold in behavioural genetics (and in genetics more generally) seems to be relatively unexplored-note that textbooks usually dedicate to the concept just a few words (see, e.g., Brooker, 2018; Klug et al., 2016; Pierce, 2017). Due to inconsistencies of the quantitative-liability model, it is worth considering more seriously the threshold model as a potential account of schizophrenia and, at the same time, as a way out from the quant/qual distinction. So, in the rest of this section, I will delineate how thresholds could be understood and what merits the threshold model has in comparison with the quantitative-liability model.

A possible way to understand the threshold model in genetic terms is that the presence of a high-enough number of 'pathological' alleles produces a 'switch' in the system. In this sense, a threshold would not just be a point arbitrarily placed on a continuum, but rather a real change in the system due to the accumulation of a given number of genetic effects. However, systemic changes of this sort are unlikely reducible to genetic factors and can rather involve specific interactions between genetic and environmental influences.

Research from outside behavioural genetics can be informative as regards the characterisation of thresholds. For instance, the concept of threshold plays a central role in the study of evolvability and plasticity of sexual and morphological development and environmental stress tolerance. Here, threshold traits are characterised as traits that have only two or a few phenotypic classes, but their development is 
determined by the effects of multiple genetic, epigenetic, and environmental effects (Ostrowski et al., 2000; Roff et al., 1997). For instance, in various species, phenotypic transitions in development can be induced by environmental stress and controlled by stress-response proteins like the Hsp90 chaperone (Milton et al., 2006; Rutherford, 2003).

In developmental terms, thresholds can be conceptualised in terms of bifurcations between stable regimes in the dynamical systems theory (Jaeger \& Monk, 2014) or in terms of branching points in alternative developmental paths in Waddington's epigenetics (Waddington, 1941, 2008). Note that the genetic factors from which these bifurcations or thresholds originate do not need to be just quantitative or additive; rather, thresholds might involve heterogeneous genetic effects, e.g., some genes with major effects plus many genes of small effects.

Let us now consider the potential merits of the threshold model. The characterisation of schizophrenia as a threshold trait seems able to overcome the difficulties involved in the standard definition of qualitative and quantitative traits. First, the model accounts for the complex, polygenic architecture of schizophrenia-which is, essentially, the good part of the concept of quantitative trait. Second, the observed discontinuity in phenotypic variation is not accounted for by single-gene variations - which is the central limitation of the concept of qualitative trait (see Section 3 ). Third, the threshold model avoids linear effects between the genotype and the phenotype-in contrast to the G-P linearity characterising the quantitative-liability model (see Section 4.2).

Moreover, the threshold model nicely accommodates the distinction between characters and states. As I argued in Section 4.2, schizophrenia can be regarded as one possible state of the human neuroendocrine-metabolic system. I also explained that the threshold model conceives of thresholds as switch-points that make the difference between two possible states of a biological system. By combining the two things, we can see that the threshold can be what makes the difference between two possible states of a neuroendocrine-metabolic character-which, as I noticed above, is to be empirically identified. ${ }^{22}$

It should be noted that many character states are qualitatively distinct from each other, e.g., sexual and morphological dimorphisms. In such cases, it would be

\footnotetext{
22 On this view, the schizophrenia state(s) would be stably associated with some symptoms and biomarkers, and this cluster of properties would allow us to distinguish between the schizophrenia state(s) and other possible states of the neuroendocrine-metabolic system.
} 
counterintuitive to think that the threshold differentiating the two possible states of a character is placed for just conventional or statistical reasons (as the quantitativeliability model suggests for mental disorders). This makes the threshold model, with its biological interpretation of thresholds and qualitative changes, an attractive alternative to a purely quantitative description of schizophrenia.

\section{Conclusions}

In this paper, I challenged the received view of quantitative and qualitative traits and proposed directions for framing phenotypes beyond such two concepts. I started by suggesting that the quant/qual distinction might owe its popularity to the assumption that it represents a powerful heuristic to understand a variety of aspects of biological organisms and their study. In this view, the concept of quantitative trait would be systematically associated with continuous variation, polygenic inheritance, and complex G-P maps; by contrast, the concept of qualitative trait would be associated with discontinuous variation, monogenic inheritance, and simple G-P maps. Then, I examined cases from Mendelian and behavioural genetics that show that this assumption is problematic because cases arise that do not fulfil the criteria usually associated with each type of trait. Moreover, the quant/qual distinction involves unwarranted simplifications on how to define phenotypic traits.

Specifically, I argued that, in the study of Mendelian traits, the standard definition of qualitative trait implies that some traits are monogenic or involve a simple G-P map; importantly, it also implies that Mendelian genes are all equally penetrant, which ignores phenomena such as incomplete penetrance, phenotypic plasticity, and robustness of biological systems. Ultimately, phenotypic development is much more complex than what the concept of qualitative trait entails: what can be qualitative, monogenic, or 'simple' is just phenotypic variation in specific and contextual conditions. Moreover, the concept of qualitative trait can lead us to take the association of single-genetic variants and phenotypic variation as a guide to provide a definition of traits themselves. The Mendelian traits and diseases here examined mistake character states as characters in order to fit such a definition.

Additionally, the standard definition of quantitative trait does not apply to mental disorders such as schizophrenia: contemporary models aimed at describing them as quantitative traits present remarkable conceptual deficiencies-the most important of which is that mental disorders are conceptualised as characters. 
For the sake of brevity, I could analyse only specific examples where the quant/qual distinction falls short of its ambitions of providing a powerful conceptual framework. Thus, it is possible that for some traits the quant/qual distinction works better than for others. Nonetheless, I suspect that the arguments and the solutions I proposed here could be generalised to other cases. For instance, it is possible that most pathological conditions (both Mendelian and non-Mendelian) are to be considered as character states, rather than characters. If so, the range of applicability of the concepts of qualitative and quantitative trait would be narrower.

Note also that, in contrast to what the received view might suggest, problems with the concept of qualitative trait would not make most traits falling under the definition of quantitative trait. Indeed, it is possible that emblematic quantitative traits like human height and IQ can be decomposed into more elementary sub-traits related to different developmental modules at different developmental stages. This would imply that, in developmental terms, such traits could not be described as involving a single dimension on which all individuals of a species can be placed (on height, see Orgogozo et al., 2015; on intelligence, see Footnote \#14). This would reduce the extension of the concept of quantitative trait, too. If so, many so-called quantitative traits might reveal to involve complex dynamical effects (e.g., thresholds) due to heterogeneous genetic factors, e.g., both a small number of highly penetrant genes and the small influence of many other genes. This would make many traits neither qualitative nor quantitative but rather, perhaps unsurprisingly, simply complex.

It is important to keep in mind that the concepts of quantitative and qualitative traits entail definitional criteria of phenotypic characteristics that can impact the way we conceptualise phenotypic development. If misconceptions of any sorts are involved, they can only have negative effects on how biological research is conducted. The inconsistencies I identified in the quant/qual distinction point to the necessity of a conceptually-sound definitional approach for biological characteristics beyond classical dichotomies. Such an approach should be capable of disentangling the causal aspects of phenotypic development from the specific idealisations and methodologies characterising different research areas.

Ultimately, the identification of phenotypic traits is only in part an empirical or methodological problem. Rather, the question is conceptual in nature. 
Acknowledgements: This research was supported by the University of Genoa. The funding source had no role other than financial support. I thank Andrea Borghini, James DiFrisco, Kate E. Lynch, Staffan Müller-Wille, Valentina Petrolini, John R. G. Turner, Marco Viola, and two anonymous reviewers for their feedback on previous versions of the manuscript. I also thank Cristina Amoretti, John Dupré, Flavia Fabris, Marcello Frixione, Gregory Radick, and Luca Rivelli for fruitful and enriching discussions on the topic.

\section{References}

Ahluwalia, K. B. (2009). Genetics. Second Edition. New Delhi: New Age International.

American Psychiatric Association (2013). Diagnostic and Statistical Manual of Mental Disorders. Fifth Edition. Arlington: American Psychiatric Publishing.

Block, N. (1995). How heritability misleads about race. Cognition, 56(2), 99-128.

Brooker, R. J. (2018). Genetics: Analysis \& Principles. Sixth Edition. New York: McGraw Hill.

Burian, R. M., \& Kampourakis, K. (2013). Against “Genes For”: Could an Inclusive Concept of Genetic Material Effectively Replace Gene Concepts?. In K. Kampourakis (Ed.), The philosophy of biology. A Companion for Educators (pp. 597-628). Springer.

Burton, P. R., Bowden, J. M., \& Tobin, M. D. (2007). Epidemiology and genetic epidemiology. In D. J. Balding, M. Bishop, \& C. Cannings (Eds.), Handbook of statistical genetics, Volume 2 (pp. 1111-1140). Wiley \& Sons.

Carlborg, O., \& Haley, C. S. (2004). Epistasis: too often neglected in complex trait studies?. Nature reviews. Genetics, 5(8), 618-625.

Chen, R., Shi, L., Hakenberg, J., Naughton, B., ... \& Sleiman, P. (2016). Analysis of 589,306 genomes identifies individuals resilient to severe Mendelian childhood diseases. Nature biotechnology, 34(5), 531-538.

Cock, A. G. (1973). William Bateson, Mendelism and Biometry. Journal of the History of Biology, 6(1), 1-36.

Colless, D. H. (1985). On "character" and related terms. Systematic Zoology, 34(2), 229-233.

Cooper, D. N., Krawczak, M., Polychronakos, C., Tyler-Smith, C., \& Kehrer-Sawatzki, H. (2013). Where genotype is not predictive of phenotype: towards an understanding of the molecular basis of reduced penetrance in human inherited disease. Human genetics, 132(10), 1077-1130.

Coyle, J. T. (2006). Glutamate and schizophrenia: beyond the dopamine hypothesis. Cellular and molecular neurobiology, 26(4-6), 363-382.

Dar-Nimrod, I., \& Heine, S. J. (2011). Genetic essentialism: on the deceptive determinism of DNA. Psychological bulletin, 137(5), 800-818.

Dietz, A. G., Goldman, S. A., \& Nedergaard, M. (2020). Glial cells in schizophrenia: a unified hypothesis. The Lancet Psychiatry, 7, 272-281. 
DiFrisco, J. (2019). Developmental Homology. In L. Nuno de la Rosa \& G. B. Müller (Eds.), Evolutionary Developmental Biology: A Reference Guide (pp. 1-13). Springer.

DiFrisco, J., \& Jaeger, J. (2019). Beyond networks: mechanism and process in evo-devo. Biology \& Philosophy, 34(6), 54.

DiFrisco, J., \& Jaeger, J. (forthcoming). Genetic causation in complex regulatory systems: an integrative dynamic perspective. BioEssays, 1900226.

Dobzhansky, T. (1970). Genetics of the evolutionary process. New York \& London: Columbia University Press.

Downes, S. M. \& Matthews, L. (2019). Heritability. In E. N. Zalta (Ed.), The Stanford Encyclopedia of Philosophy. https://plato.stanford.edu/archives/win2019/entries/heredity

East, E. M. (1910). A Mendelian interpretation of variation that is apparently continuous. The American Naturalist, 44(518), 65-82.

Eley, T. C., \& Rijsdijk, F. (2005). Introductory guide to the statistics of molecular genetics. Journal of Child Psychology and Psychiatry, 46(10), 1042-1044.

Falconer, D. S. (1965). The inheritance of liability to certain diseases, estimated from the incidence among relatives. Annals of human genetics, 29(1), 51-76.

Falconer, D. S., \& Mackay, T. F. C. (1996). Introduction to quantitative genetics. Essex: Longman Group.

Fisher, R. A. (1918). The Correlation Between Relatives on the Supposition of Mendelian Inheritance. Transactions of the Royal Society of Edinburgh, 52, 399-433.

Fisher, R. A., Immer, F. R., \& Tedin, O. (1932). The genetical interpretation of statistics of the third degree in the study of quantitative inheritance. Genetics, 17(2), 107-124.

Freudenstein, J. V. (2005). Characters, states and homology. Systematic biology, 54(6), 965973.

Fristrup, K. M. (2001). A history of character concepts in evolutionary biology. In G. P. Wagner (Ed.), The character concept in evolutionary biology (pp. 15-37). Academic Press.

Fusar-Poli, P., Borgwardt, S., Bechdolf, A., ... \& Valmaggia, L. (2013). The psychosis high-risk state: a comprehensive state-of-the-art review. JAMA Psychiatry, 70(1), 107-120.

Galton, F. (1894). Natural inheritance. London: Macmillan \& Co.

Gottlieb, G. (1995). Some conceptual deficiencies in 'developmental' behavior genetics. $\mathrm{Hu}$ man Development, 38(3), 131-141.

Griffing, B. (1950). Analysis of quantitative gene action by constant parent regression and related techniques. Genetics, 35(3), 303-321.

Griffiths, P., \& Stotz, K. (2013). Genetics and philosophy: An introduction. Cambridge, UK: Cambridge University Press.

Hartl, D. L., \& Jones, E. W. (1998). Genetics: Principles and Analysis. Fourth Edition. Sudbury, MA: Jones and Bartlett Publishers.

Hartwell, L., Goldberg, M. L., Fischer, J. A., \& Hood, L. E. (2018). Genetics: From Genes to Genomes. Sixth Edition. New York: McGraw-Hill. 
Haslam, N. (2014). Natural Kinds in Psychiatry: Conceptually Implausible, Empirically Questionable, and Stigmatizing. In H. Kincaid \& J. A. Sullivan (Eds.), Classifying Psychopathology. Mental kinds and natural kinds (pp. 11-28). Cambridge, US: MIT Press.

Insel, T. R. (2010). Rethinking schizophrenia. Nature, 468(7321), 187-193

Insel, T. R. (2014). The NIMH research domain criteria (RDoC) project: precision medicine for psychiatry. American Journal of Psychiatry, 171(4), 395-397.

Jaeger, J., \& Monk, N. (2014). Bioattractors: dynamical systems theory and the evolution of regulatory processes. The Journal of physiology, 592(11), 2267-2281.

Jamieson, A., \& Radick, G. (2013). Putting Mendel in his place: how curriculum reform in genetics and counterfactual history of science can work together. In K. Kampourakis (Ed.), The philosophy of biology. A Companion for Educators (pp. 577-595). Springer.

Jang, K. L. (2005). The behavioral genetics of psychopathology: A clinical guide. Mahwah: Lawrence Erlbaum Associates.

Johannsen, W. (1903). Über Erblichkeit in Populationen und in reinen Linien. Gustav Fischer Verl, Jena.

Katsanis, N. (2016). The continuum of causality in human genetic disorders. Genome biology, 17(1), 233.

Keil, G., Keuck, L., \& Hauswald, R. (Eds.). (2017). Vagueness in psychiatry. Oxford: Oxford University Press.

Kempthorne, O. (1978). A Biometrics Invited Paper: Logical, Epistemological and Statistical Aspects of Nature-Nurture Data Interpretation. Biometrics, 34(1), 1-23.

Kendler, K. S. (2005). "A gene for...": the nature of gene action in psychiatric disorders. American Journal of Psychiatry, 162(7), 1243-1252.

Kendler, K. S. (2014). The dopamine hypothesis of schizophrenia: an updated perspective. In K. S. Kendler \& J. Parnas (Eds.), Philosophical issues in psychiatry III: The Nature and Sources of Historical Change (pp. 283-294). Oxford: Oxford University Press.

Klug, W. S., Cummings, M. R., Spencer, C. A., Palladino, M. A., \& Ward, S. M. (2016). Concepts of genetics. Eleventh Edition. Pearson.

Knopik, V. S., Neiderhiser, J. M., DeFries, J. C., \& Plomin, R. (2017). Behavioral genetics. Seventh Edition. New York: Macmillan.

Kovacs, K., \& Conway, A. R. (2016). Process overlap theory: A unified account of the general factor of intelligence. Psychological Inquiry, 27(3), 151-177.

Kray, J., \& Frensch, P. (2002). A View From Cognitive Psychology: $g-(G)$ host in the Correlation Matrix? In R. Sternberg \& E. Grigorenko (Eds.), The General Factor of Intelligence. How General is it? (pp. 183-220). Mahwah: Lawrence Erlbaum.

Lawrence, E. (Ed.). (2008). Henderson's dictionary of biology. Fourteenth Edition. Harlow: Pearson Education.

Lewontin, R. (1974). Annotation: the analysis of variance and the analysis of causes. American journal of human genetics, 26(3), 400-411. 
Lynch, K. E. (under review). The meaning of cause in genetics. In J. B. Pingault, R. Richmond, \& G. Davey Smith (Eds.), Genetics meets causal inference: Understanding modifiable risks in human health and development. New York: Cold Spring Harbor Laboratory Press.

Mather, K. (1941). Variation and selection of polygenic characters. Journal of Genetics, 41(1), 159-193.

Mather, K. (1943). Polygenic Inheritance and Natural Selection. Biological Reviews, 18(1), 32-64.

Mather, K. (1964). Human Diversity. The Nature and Significance of Differences Among Men. Edinburgh: Oliver \& Boyd.

Mather, K., \& Jinks, J. L. (1982). Biometrical genetics: The study of continuous variation. London: Chapman \& Hall.

McDonald, J. H. (2012). Myths of Human Genetics: Introduction to the Myths, http://udel.edu/ mcdonald/mythintro.html (Accessed 22 July 2019).

Mendel, G. (1866). Versuche über Pflanzen-Hybriden. Verhandlungen des Naturforschenden Vereines in Brünn, IV.

Milton, C. C., Ulane, C. M., \& Rutherford, S. (2006). Control of canalization and evolvability by Hsp90. PloS one, 1(1), e75, 1-12.

Morgan, T. H., Sturtevant, A. H., Muller, H. J., \& Bridges, C. B. (1915). The mechanism of mendelian heredity. New York: Henry Holt and Company.

Morrison, M. (2007). The development of population genetics. In M. Matthen \& C. Stephens (Eds.), Philosophy of Biology (pp. 309-333). Amsterdam: Elsevier.

Müller-Wille, S., \& Richmond, M. L. (2016). Revisiting the Origins of Genetics. In S. MüllerWille \& C. Brandt (Eds.), Heredity Explored: Between Public Domain and Experimental Science, 1850-1930 (pp. 367-394). Cambridge, US: MIT Press.

Nelson, R. M., Pettersson, M. E., \& Carlborg, O. (2013). A century after Fisher: time for a new paradigm in quantitative genetics. Trends in Genetics, 29(12), 669-676.

Nilsson-Ehle, H. (1909). Kreuzungsuntersuchungen an hafer und weizen (Vol. 20, No. 2). H. Ohlssons buchdruckerei.

Norton, B. (1975). Metaphysics and population genetics: Karl Pearson and the background to Fisher's multi-factorial theory of inheritance. Annals of Science, 32(6), 537-553.

Okasha, S. (2009). Causation in biology. In P. Menzies, H. Beebee, \& C. Hitchcock (Eds.) The Oxford Handbook of Causation (pp. 707-725). Oxford, UK: Oxford University Press.

Online Mendelian Inheritance in Man, OMIM ${ }^{\circledR}$. McKusick-Nathans Institute of Genetic Medicine, Johns Hopkins University (Baltimore, MD), 2019, https://omim.org (Accessed 18 August 2019).

Orgogozo, V., Morizot, B., \& Martin, A. (2015). The differential view of genotype-phenotype relationships. Frontiers in genetics, 6(179), 1-14. 
Ostrowski, M. F., Jarne, P., \& David, P. (2000). Quantitative genetics of sexual plasticity: the environmental threshold model and genotype-by-environment interaction for phallus development in the snail Bulinus truncatus. Evolution, 54(5), 1614-1625.

Pearson, K. (1900). The Grammar of Science. Second Edition. London: Adam \& Charles Black.

Pierce, B. A. (2017). Genetics: A conceptual approach, Sixth Edition. New York: Freeman \& Company.

Plomin, R., DeFries, J. C., Knopik, V. S., \& Neiderhiser, J. N. (2013). Behavioral Genetics. Sixth Edition. New York: Worth Publishers.

Plomin, R., Haworth, C. M. A., \& Davis, O. S. P. (2009). Common disorders are quantitative traits. Nature Reviews Genetics, 10, 872-878.

Pollock, C. (1989). The Genetics of Eye Color in Drosophila melanogaster. Tested Studies for Laboratory Teaching, 141-155.

Porter, T. M. (2005). The Biometric Sense of Heredity: Statistics, Pangenesis and Positivism. In S. Müller-Wille \& H. J. Rheinberger (Eds.), A Cultural History of Heredity III: 19th and Early 20th Centuries (pp. 31-42). Max Planck Institute for the History of Science.

Provine, W. B. (1971). The origins of theoretical population genetics. Chicago: University of Chicago Press.

Purcell, S. (2013). Appendix. Statistical Methods in Behavioral Genetics. In R. Plomin, J. C. DeFries, V. S. Knopkin \& J. N. Neiderhiser, Behavioral Genetics. Sixth Edition (pp. 357-411). New York: Worth Publishers.

Radick, G. (2005). Other histories, other biologies. Royal Institute of Philosophy Supplements, $56,21-47$.

Radick, G. (2011). Physics in the Galtonian sciences of heredity. Studies in History and Philosophy of Biological and Biomedical Sciences, 42(2), 129-138.

Ratner, C. (2004). Genes and psychology in the news. New Ideas in Psychology, 22(1), 29-47.

Rheinberger, H. J., Müller-Wille, S., \& Meunier, R. (2015). Gene. In E. N. Zalta (Ed.), The Stanford Encyclopedia of Philosophy. https://plato.stanford.edu/archives/spr2015/entries/gene

Roff, D. A., Stirling, G., \& Fairbairn, D. J. (1997). The evolution of threshold traits: a quantitative genetic analysis of the physiological and life-history correlates of wing dimorphism in the sand cricket. Evolution, 51(6), 1910-1919.

Roll-Hansen, N. (1978). The genotype theory of Wilhelm Johannsen and its relation to plant breeding and the study of evolution. Centaurus, 22(3), 201-235.

Rutherford, S. L. (2003). Between genotype and phenotype: protein chaperones and evolvability. Nature Reviews Genetics, 4(4), 263-274

Schwartz, J. (2009). In pursuit of the gene. Cambridge, MA: Harvard University Press.

Scriver, C. R. (2007). The PAH gene, phenylketonuria, and a paradigm shift. Human Mutation, 28, 831-845. 
Serpico, D. (2018). What kind of kind is intelligence?. Philosophical Psychology, 31(2), 232252.

Snustad, D. P., \& Simmons, M. J. (2012). Principles of genetics. Sixth Edition. New York: Wiley. Stamhuis, I. H. (1995). A female contribution to early genetics: Tine Tammes and Mendel's laws for continuous characters. Journal of the History of Biology, 28(3), 495-531.

Strachan, T., \& Read, A. P. (2011). Human molecular genetics. Fourth Edition. New York: Garland Science.

Sturm, R. A., \& Frudakis, T. N. (2004). Eye colour: portals into pigmentation genes and ancestry. Trends in Genetics, 20(8), 327-332.

Tabery, J. (2014). Beyond versus: The struggle to understand the interaction of nature and nurture. Cambridge, US: MIT Press.

Tammes, T. (1911). Das Verhalten fluktuierend variierender Merkmale bei der Bastardierung. Recueil des travaux botaniques Neerlandais, 8(3/4), 201-288.

Turkheimer, E. (2011). Still missing. Research in Human Development, 8(3-4), 227-241.

Van der Maas, H. J. L., Dolan, C. V., Grasman, R. P. P. P., et al. (2006). A dynamical model of general intelligence: the positive manifold of intelligence by mutualism. Psychological review, 113(4), 842-861.

Visscher, P. M., \& Goddard, M. E. (2019). From RA Fisher's 1918 paper to GWAS a century later. Genetics, 211(4), 1125-1130.

Visscher, P. M., Hill, W. G., \& Wray, N. R. (2008). Heritability in the genomics era--concepts and misconceptions. Nature reviews. Genetics, 9(4), 255-266.

Waddington, C. H. (1941). Evolution of developmental systems. Nature, 147(3717), 108110.

Waddington, C. H. (2008). The basic ideas of biology. Biological Theory, 3(3), 238-253.

Wagner, G. P. W. (2014). Homology, genes, and evolutionary innovation. Princeton: Princeton University Press.

Waters, C. K. (2007). Causes that make a difference. The Journal of Philosophy, 104(11), 551579.

Wilson, J. (2017). Determinables and Determinates. In E. N. Zalta (Ed.), The Stanford Encyclopedia of Philosophy. https://plato.stanford.edu/archives/spr2017/entries/determinate-determinables

Yule, G. U. (1902). Mendel's Laws and their Probable Relations to Intra-Racial Heredity. New Phytologist, 1(10), 222-238.

Zachar, P. (2000). Psychiatric disorders are not natural kinds. Philosophy, Psychiatry, \& Psychology, 7(3), 167-182.

Zhu, M., Yu, M., \& Zhao, S. (2009). Understanding quantitative genetics in the systems biology era. International journal of biological sciences, 5(2), 161-170. 


\section{Electronic Supplementary Material}

Article: Beyond Quantitative and Qualitative Traits: Three Telling Cases in the Life Sciences DOI: https://doi.org/10.1007/s10539-020-09750-6

Author: Davide Serpico, Department of Classics, Philosophy and History, University of Genoa Journal: Biology \& Philosophy

\section{Appendix: Bibliometric Research on the Web of Science Database}

Below are summarised the results of a bibliometric research on the database of Web of Science (Core Collection) (accessed August 2019).

Four queries (i.e., Topics, 'TS') have been investigated through the Advanced Search tool:

1. $\mathrm{TS}=($ "quantitative trait*" OR "quantitative character*")

2. $\mathrm{TS}=$ ("qualitative trait*" OR "qualitative character*”)

3. $\mathrm{TS}=($ "qualitative trait*" OR "qualitative character*" OR "Mendelian trait*" OR "Mendelian character*" OR "Mendelian disease*")

4. TS=("quantitative trait*" AND "qualitative trait*" OR "quantitative character*" AND "qualitative character*")

Below the results of each query are included:

- Bar Graph per year of publication

- Bar Graph and Records per research area

- The criteria used for refining the research (i.e., Document Type and Categories)

The Web of Science database is accessible at: https://login.webofknowledge.com 
QUERY 1: TS=(“quantitative trait*" OR "quantitative character*”)

Results: 37,715

Timespan: All years (1985-2019)

Indexes: SCI-EXPANDED, SSCI, A\&HCI, CPCI-S, CPCI-SSH, ESCI

Bar Graph 1: Query (“quantitative trait*” OR "quantitative character*”) per year of publication

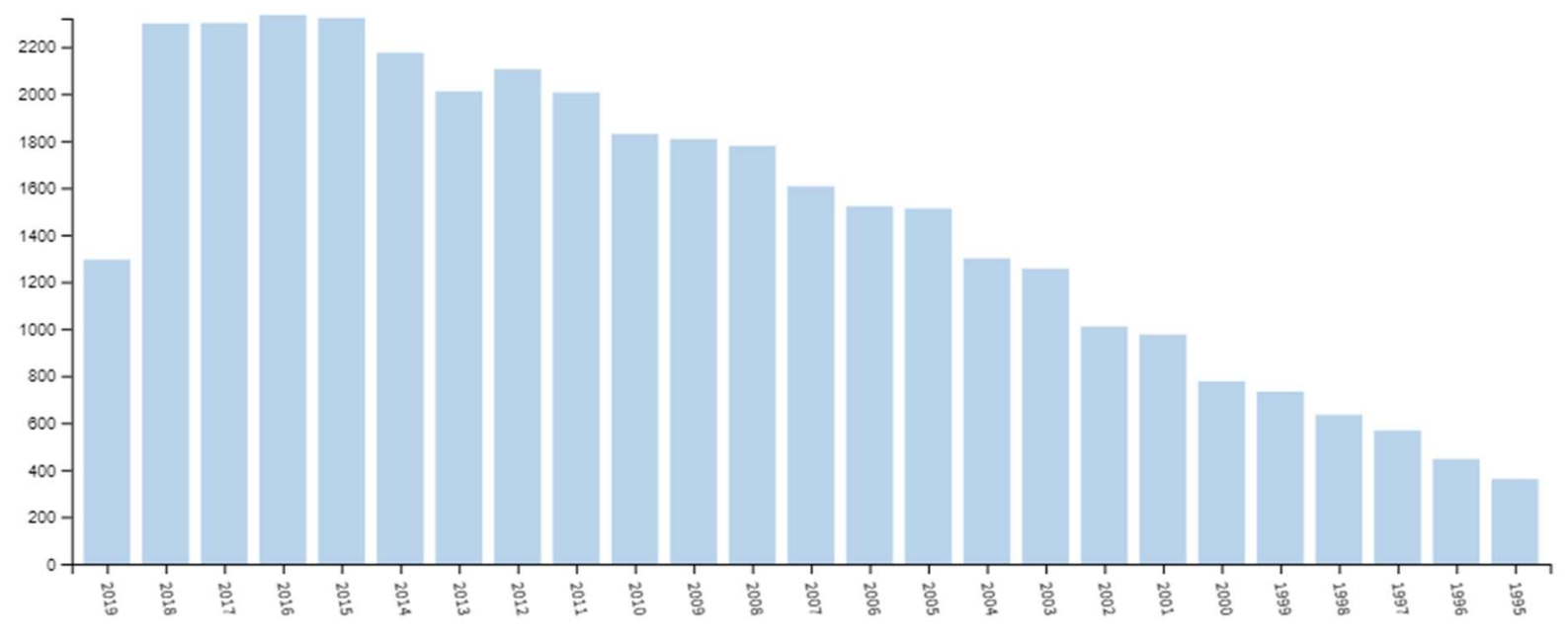

Bar Graph 2: Query (“quantitative trait*” OR "quantitative character*”) per research area

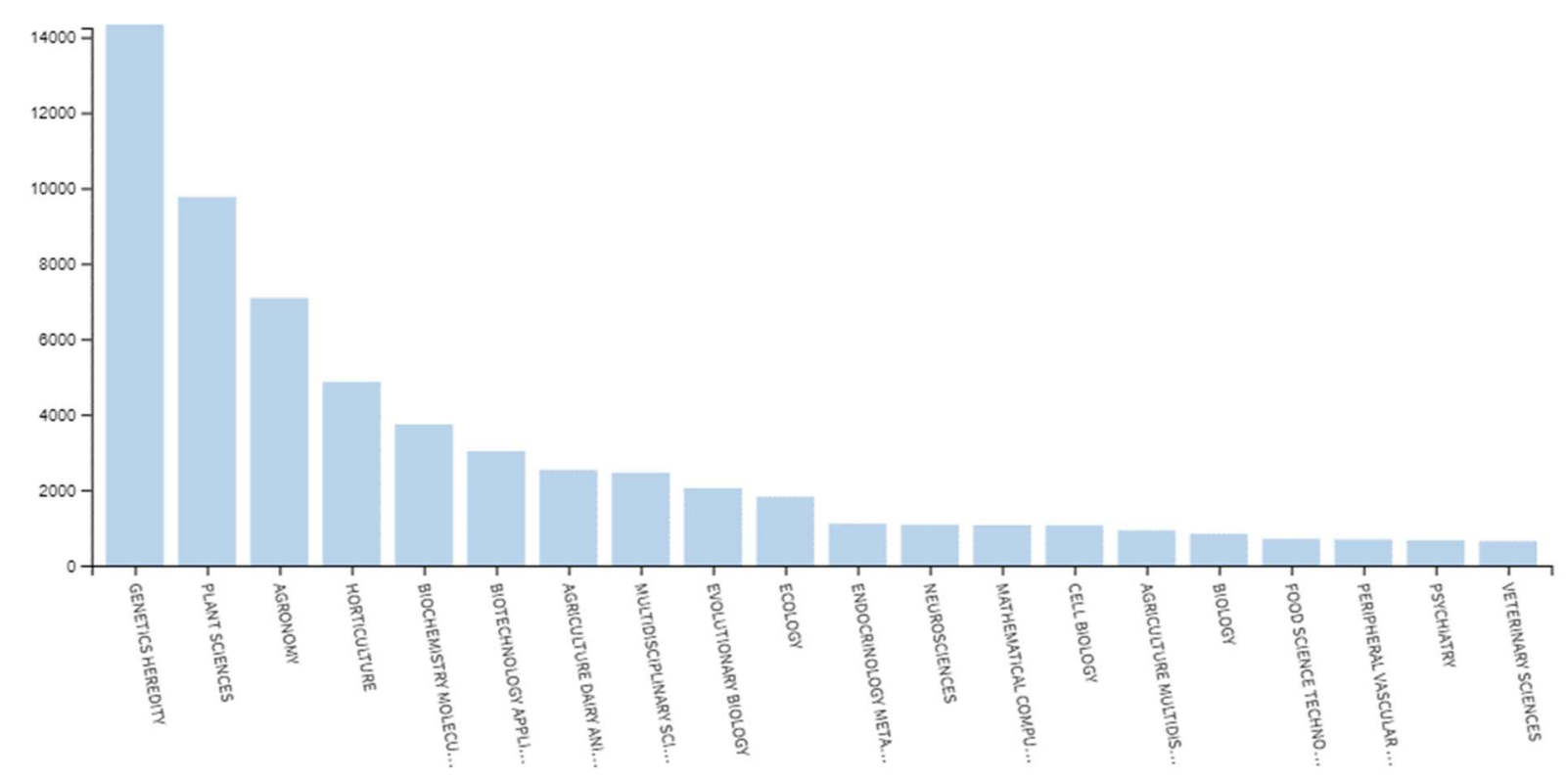




\begin{tabular}{|c|c|c|}
\hline Web of Science Categories & records & $\%$ of 37715 \\
\hline GENETICS HEREDITY & 14251 & 37.786 \\
\hline PLANT SCIENCES & 9688 & 25.687 \\
\hline AGRONOMY & 7003 & 18.568 \\
\hline HORTICULTURE & 4779 & 12.671 \\
\hline BIOCHEMISTRY MOLECULAR BIOLOGY & 3652 & 9.683 \\
\hline BIOTECHNOLOGY APPLIED MICROBIOLOGY & 2934 & 7.779 \\
\hline AGRICULTURE DAIRY ANIMAL SCIENCE & 2437 & 6.462 \\
\hline MULTIDISCIPLINARY SCIENCES & 2367 & 6.276 \\
\hline EVOLUTIONARY BIOLOGY & 1963 & 5.205 \\
\hline ECOLOGY & 1728 & 4.582 \\
\hline ENDOCRINOLOGY METABOLISM & 1009 & 2.675 \\
\hline NEUROSCIENCES & 986 & 2.614 \\
\hline MATHEMATICAL COMPUTATIONAL BIOLOGY & 985 & 2.612 \\
\hline CELL BIOLOGY & 973 & 2.580 \\
\hline AGRICULTURE MULTIDISCIPLINARY & 839 & 2.225 \\
\hline BIOLOGY & 748 & 1.983 \\
\hline FOOD SCIENCE TECHNOLOGY & 607 & 1.609 \\
\hline PERIPHERAL VASCULAR DISEASE & 602 & 1.596 \\
\hline PSYCHIATRY & 584 & 1.548 \\
\hline VETERINARY SCIENCES & 555 & 1.472 \\
\hline BEHAVIORAL SCIENCES & 518 & 1.373 \\
\hline PHYSIOLOGY & 460 & 1.220 \\
\hline BIOCHEMICAL RESEARCH METHODS & 428 & 1.135 \\
\hline IMMUNOLOGY & 424 & 1.124 \\
\hline FORESTRY & 415 & 1.100 \\
\hline PHARMACOLOGY PHARMACY & 395 & 1.047 \\
\hline CHEMISTRY MULTIDISCIPLINARY & 354 & 0.939 \\
\hline ZOOLOGY & 321 & 0.851 \\
\hline MEDICINE RESEARCH EXPERIMENTAL & 289 & 0.766 \\
\hline ONCOLOGY & 286 & 0.758 \\
\hline CARDIAC CARDIOVASCULAR SYSTEMS & 275 & 0.729 \\
\hline HEMATOLOGY & 274 & 0.727 \\
\hline PSYCHOLOGY MULTIDISCIPLINARY & 268 & 0.711 \\
\hline CLINICAL NEUROLOGY & 254 & 0.673 \\
\hline NUTRITION DIETETICS & 244 & 0.647 \\
\hline SUBSTANCE ABUSE & 214 & 0.567 \\
\hline ENTOMOLOGY & 192 & 0.509 \\
\hline BIOPHYSICS & 183 & 0.485 \\
\hline ENVIRONMENTAL SCIENCES & 183 & 0.485 \\
\hline MICROBIOLOGY & 169 & 0.448 \\
\hline DEVELOPMENTAL BIOLOGY & 132 & 0.350 \\
\hline ANTHROPOLOGY & 128 & 0.339 \\
\hline TOXICOLOGY & 124 & 0.329 \\
\hline RHEUMATOLOGY & 119 & 0.316 \\
\hline CHEMISTRY ORGANIC & 113 & 0.300 \\
\hline UROLOGY NEPHROLOGY & 108 & 0.286 \\
\hline GASTROENTEROLOGY HEPATOLOGY & 103 & 0.273 \\
\hline REPRODUCTIVE BIOLOGY & 92 & 0.244 \\
\hline PARASITOLOGY & 90 & 0.239 \\
\hline BIODIVERSITY CONSERVATION & 89 & 0.236 \\
\hline RESPIRATORY SYSTEM & 77 & 0.204 \\
\hline PATHOLOGY & 70 & 0.186 \\
\hline INFECTIOUS DISEASES & 67 & 0.178 \\
\hline MYCOLOGY & 64 & 0.170 \\
\hline VIROLOGY & 61 & 0.162 \\
\hline PSYCHOLOGY & 47 & 0.125 \\
\hline COMPUTER SCIENCE INTERDISCIPLINARY APPLICATIONS & 44 & 0.117 \\
\hline PSYCHOLOGY DEVELOPMENTAL & 44 & 0.117 \\
\hline MICROSCOPY & 42 & 0.111 \\
\hline PALEONTOLOGY & 31 & 0.082 \\
\hline DERMATOLOGY & 30 & 0.080 \\
\hline PSYCHOLOGY BIOLOGICAL & 27 & 0.072 \\
\hline ORNITHOLOGY & 12 & 0.032 \\
\hline PSYCHOLOGY SOCIAL & 12 & 0.032 \\
\hline NEUROIMAGING & 11 & 0.029 \\
\hline HISTORY PHILOSOPHY OF SCIENCE & 9 & 0.024 \\
\hline HUMANITIES MULTIDISCIPLINARY & 7 & 0.019 \\
\hline SOCIOLOGY & 6 & 0.016 \\
\hline
\end{tabular}




\begin{tabular}{|l|c|c|}
\hline ENVIRONMENTAL STUDIES & 5 & 0.013 \\
\hline PSYCHOLOGY APPLIED & 1 & 0.003 \\
\hline
\end{tabular}

Refined by: DOCUMENT TYPES: ( ARTICLE OR BOOK CHAPTER OR PROCEEDINGS PAPER OR REVIEW OR MEETING ABSTRACT ) AND [excluding]WEB OF SCIENCE CATEGORIES: ( MEDICINE GENERAL INTERNAL OR CHEMISTRY ANALYTICAL OR OPTICS OR PUBLIC ENVIRONMENTAL OCCUPATIONAL HEALTH OR RADIOLOGY NUCLEAR MEDICINE MEDICAL IMAGING OR MATERIALS SCIENCE CHARACTERIZATION TESTING OR MARINE FRESHWATER BIOLOGY OR GERIATRICS GERONTOLOGY OR METALLURGY METALLURGICAL ENGINEERING OR COMPUTER SCIENCE THEORY METHODS OR COMPUTER SCIENCE ARTIFICIAL INTELLIGENCE OR NANOSCIENCE NANOTECHNOLOGY OR FISHERIES OR MATERIALS SCIENCE MULTIDISCIPLINARY OR SPECTROSCOPY OR ENGINEERING BIOMEDICAL OR ENGINEERING MULTIDISCIPLINARY OR PHYSICS CONDENSED MATTER OR ENGINEERING CHEMICAL OR MATERIALS SCIENCE COATINGS FILMS OR ENERGY FUELS OR MATHEMATICS APPLIED OR OCEANOGRAPHY OR CHEMISTRY PHYSICAL OR GEOSCIENCES MULTIDISCIPLINARY OR COMPUTER SCIENCE INFORMATION SYSTEMS OR PHYSICS MULTIDISCIPLINARY OR GEOCHEMISTRY GEOPHYSICS OR STATISTICS PROBABILITY OR ENGINEERING ENVIRONMENTAL OR CHEMISTRY APPLIED OR PHYSICS FLUIDS PLASMAS OR ENGINEERING MECHANICAL OR WATER RESOURCES OR PHYSICS APPLIED OR PHYSICS ATOMIC MOLECULAR CHEMICAL OR SOIL SCIENCE OR PHYSICS MATHEMATICAL OR ENGINEERING CIVIL OR POLYMER SCIENCE OR AGRICULTURAL ENGINEERING OR INSTRUMENTS INSTRUMENTATION OR MECHANICS OR OBSTETRICS GYNECOLOGY OR ENGINEERING ELECTRICAL ELECTRONIC OR OPHTHALMOLOGY ) AND [excluding]WEB OF SCIENCE CATEGORIES: ( PEDIATRICS OR SPORT SCIENCES OR ASTRONOMY ASTROPHYSICS OR ORTHOPEDICS OR ALLERGY OR ANATOMY MORPHOLOGY OR CRITICAL CARE MEDICINE OR ECONOMICS OR CHEMISTRY MEDICINAL OR PSYCHOLOGY EXPERIMENTAL OR DENTISTRY ORAL SURGERY MEDICINE OR METEOROLOGY ATMOSPHERIC SCIENCES OR SURGERY OR MATHEMATICS INTERDISCIPLINARY APPLICATIONS OR GEOLOGY OR CRYSTALLOGRAPHY OR CHEMISTRY INORGANIC NUCLEAR OR PSYCHOLOGY CLINICAL OR TROPICAL MEDICINE OR EDUCATION EDUCATIONAL RESEARCH OR MATERIALS SCIENCE CERAMICS OR MATHEMATICS OR AUDIOLOGY SPEECH LANGUAGE PATHOLOGY OR ELECTROCHEMISTRY OR MANAGEMENT OR MATERIALS SCIENCE COMPOSITES OR REHABILITATION OR MEDICAL LABORATORY TECHNOLOGY OR REMOTE SENSING OR OTORHINOLARYNGOLOGY OR ANESTHESIOLOGY OR GREEN SUSTAINABLE SCIENCE TECHNOLOGY OR IMAGING SCIENCE PHOTOGRAPHIC TECHNOLOGY OR PSYCHOLOGY EDUCATIONAL OR BUSINESS FINANCE OR TRANSPLANTATION OR LINGUISTICS OR SOCIAL SCIENCES INTERDISCIPLINARY OR ENGINEERING GEOLOGICAL OR GEOGRAPHY PHYSICAL OR MINING MINERAL PROCESSING OR ENGINEERING MANUFACTURING OR NUCLEAR SCIENCE TECHNOLOGY OR BUSINESS OR EDUCATION SPECIAL OR LANGUAGE LINGUISTICS OR MATERIALS SCIENCE PAPER WOOD OR AUTOMATION CONTROL SYSTEMS OR PHYSICS PARTICLES FIELDS OR ACOUSTICS OR CELL TISSUE ENGINEERING OR MINERALOGY OR OPERATIONS RESEARCH MANAGEMENT SCIENCE OR ENGINEERING INDUSTRIAL OR PHYSICS NUCLEAR OR AGRICULTURAL ECONOMICS POLICY OR ENGINEERING AEROSPACE OR GEOGRAPHY OR MEDICAL INFORMATICS OR MEDICINE LEGAL OR COMPUTER SCIENCE SOFTWARE ENGINEERING OR INTEGRATIVE COMPLEMENTARY MEDICINE OR MATERIALS SCIENCE BIOMATERIALS OR REGIONAL URBAN PLANNING OR HISTORY OR INFORMATION SCIENCE LIBRARY SCIENCE OR MATERIALS SCIENCE TEXTILES OR ROBOTICS OR SOCIAL SCIENCES MATHEMATICAL METHODS OR DEMOGRAPHY OR EDUCATION SCIENTIFIC DISCIPLINES OR TRANSPORTATION SCIENCE TECHNOLOGY OR ARCHAEOLOGY OR COMPUTER SCIENCE CYBERNETICS OR ENGINEERING PETROLEUM OR HEALTH CARE SCIENCES SERVICES OR NURSING OR AREA STUDIES OR COMPUTER SCIENCE HARDWARE ARCHITECTURE OR CONSTRUCTION BUILDING TECHNOLOGY OR HOSPITALITY LEISURE SPORT TOURISM OR SOCIAL ISSUES OR TRANSPORTATION OR URBAN STUDIES OR CRIMINOLOGY PENOLOGY OR ENGINEERING MARINE OR ETHICS OR POLITICAL SCIENCE OR TELECOMMUNICATIONS OR ANDROLOGY OR ARCHITECTURE OR ERGONOMICS OR LAW OR LIMNOLOGY OR LOGIC OR MEDICAL ETHICS OR PUBLIC ADMINISTRATION OR THERMODYNAMICS OR ART OR COMMUNICATION OR CULTURAL STUDIES OR EMERGENCY MEDICINE OR ENGINEERING OCEAN OR GERONTOLOGY OR HEALTH POLICY SERVICES OR MUSIC OR PSYCHOLOGY MATHEMATICAL ) 
QUERY 2: TS=("qualitative trait*" OR “qualitative character*”)

Results: 2,464

Timespan: All years (1985-2019)

Indexes: SCI-EXPANDED, SSCI, A\&HCI, CPCI-S, CPCI-SSH, ESCI.

Bar Graph 3: Query (“qualitative trait*" OR "qualitative character*”) per year of publication

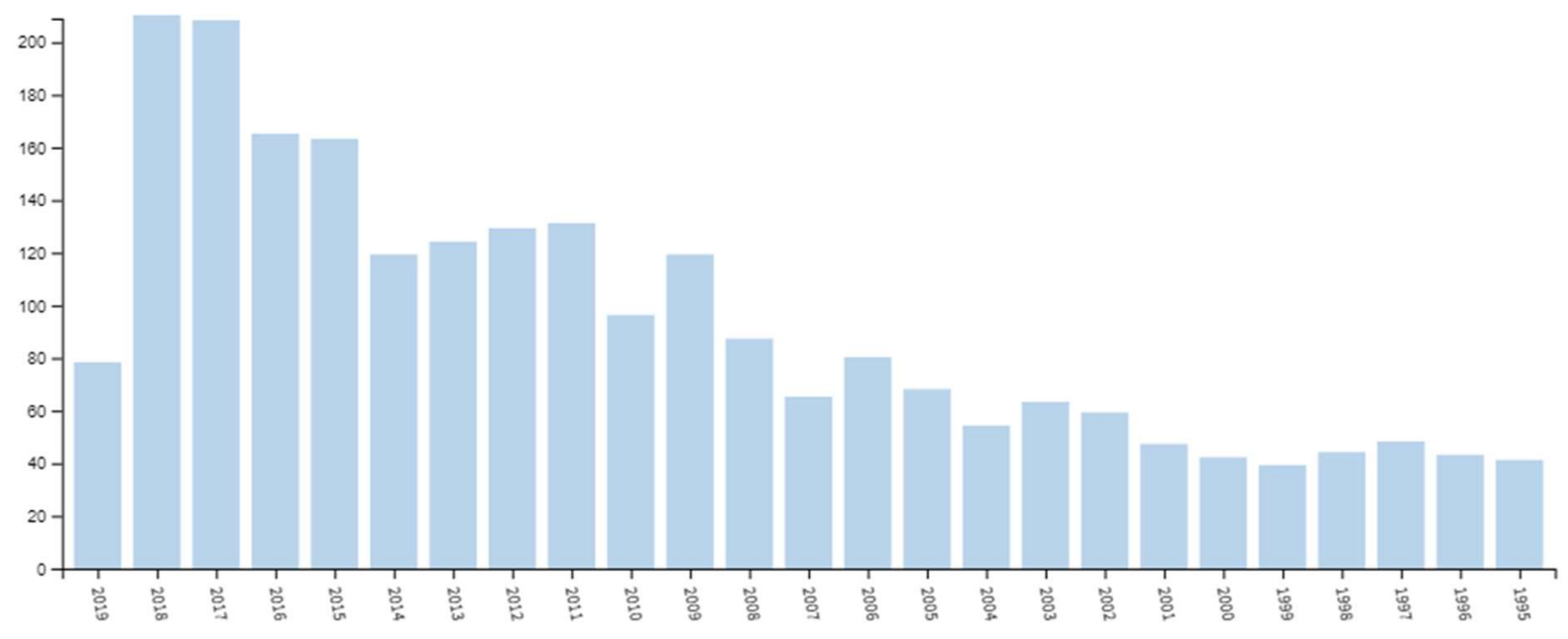

Bar Graph 4: Query ("qualitative trait*” OR "qualitative character*”) per research area

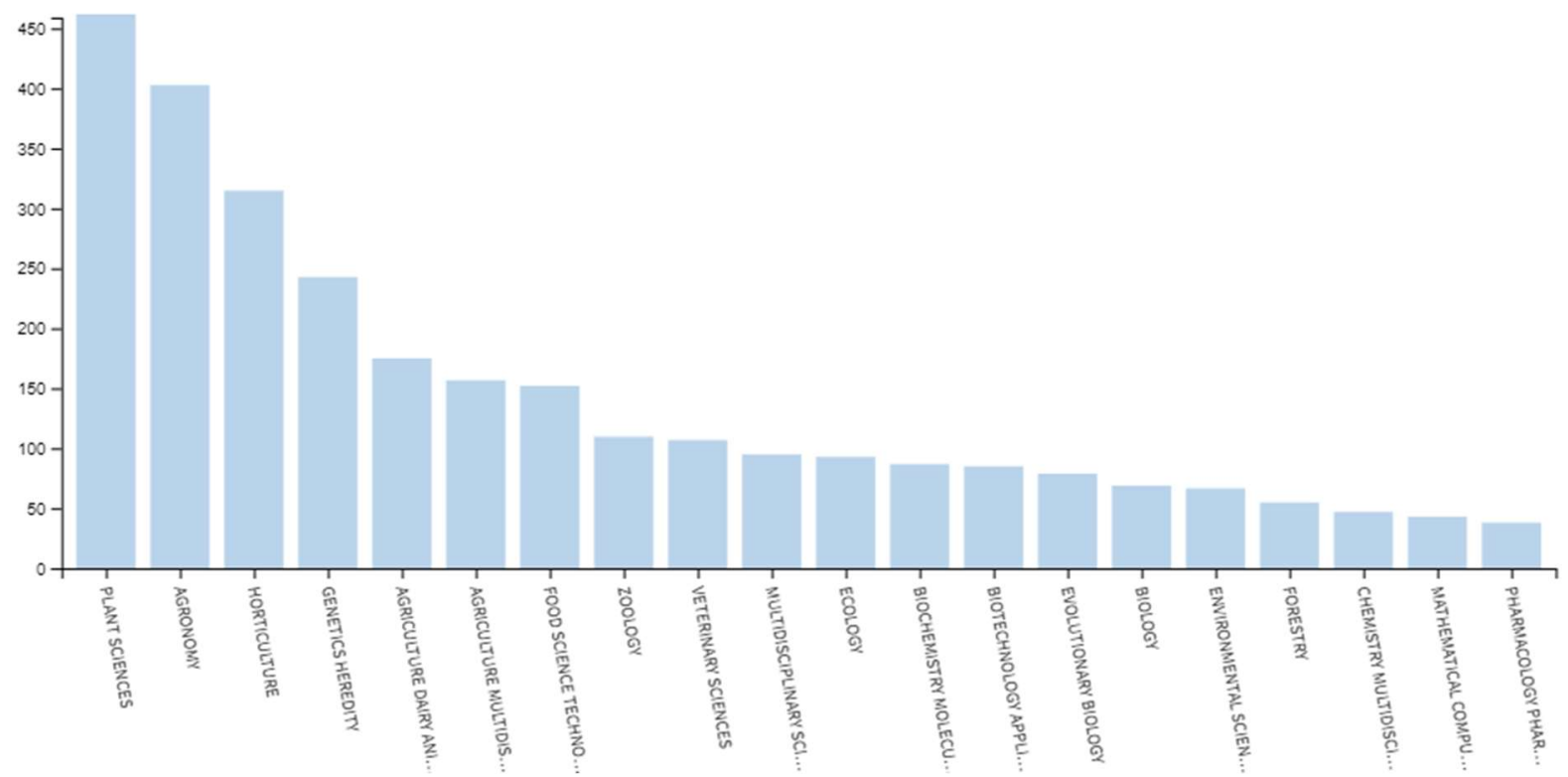




\begin{tabular}{|c|c|c|}
\hline Web of Science Categories & records & $\%$ of 2464 \\
\hline PLANT SCIENCES & 459 & 18.628 \\
\hline AGRONOMY & 400 & 16.234 \\
\hline HORTICULTURE & 312 & 12.662 \\
\hline GENETICS HEREDITY & 240 & 9.740 \\
\hline AGRICULTURE DAIRY ANIMAL SCIENCE & 172 & 6.981 \\
\hline AGRICULTURE MULTIDISCIPLINARY & 154 & 6.250 \\
\hline FOOD SCIENCE TECHNOLOGY & 149 & 6.047 \\
\hline ZOOLOGY & 107 & 4.343 \\
\hline VETERINARY SCIENCES & 104 & 4.221 \\
\hline MULTIDISCIPLINARY SCIENCES & 92 & 3.734 \\
\hline ECOLOGY & 90 & 3.653 \\
\hline BIOCHEMISTRY MOLECULAR BIOLOGY & 84 & 3.409 \\
\hline BIOTECHNOLOGY APPLIED MICROBIOLOGY & 82 & 3.328 \\
\hline EVOLUTIONARY BIOLOGY & 76 & 3.084 \\
\hline BIOLOGY & 66 & 2.679 \\
\hline ENVIRONMENTAL SCIENCES & 64 & 2.597 \\
\hline FORESTRY & 52 & 2.110 \\
\hline CHEMISTRY MULTIDISCIPLINARY & 44 & 1.786 \\
\hline MATHEMATICAL COMPUTATIONAL BIOLOGY & 40 & 1.623 \\
\hline PHARMACOLOGY PHARMACY & 35 & 1.420 \\
\hline NEUROSCIENCES & 34 & 1.380 \\
\hline BIODIVERSITY CONSERVATION & 29 & 1.177 \\
\hline MEDICINE RESEARCH EXPERIMENTAL & 28 & 1.136 \\
\hline PSYCHOLOGY MULTIDISCIPLINARY & 26 & 1.055 \\
\hline NUTRITION DIETETICS & 25 & 1.015 \\
\hline ONCOLOGY & 25 & 1.015 \\
\hline PHILOSOPHY & 25 & 1.015 \\
\hline CARDIAC CARDIOVASCULAR SYSTEMS & 23 & 0.933 \\
\hline CELL BIOLOGY & 23 & 0.933 \\
\hline MEDICINE GENERAL INTERNAL & 23 & 0.933 \\
\hline SOCIAL SCIENCES INTERDISCIPLINARY & 23 & 0.933 \\
\hline ENTOMOLOGY & 22 & 0.893 \\
\hline PSYCHOLOGY EXPERIMENTAL & 22 & 0.893 \\
\hline IMMUNOLOGY & 21 & 0.852 \\
\hline PSYCHIATRY & 20 & 0.812 \\
\hline CHEMISTRY MEDICINAL & 17 & 0.690 \\
\hline CLINICAL NEUROLOGY & 17 & 0.690 \\
\hline ENDOCRINOLOGY METABOLISM & 16 & 0.649 \\
\hline REPRODUCTIVE BIOLOGY & 16 & 0.649 \\
\hline OPHTHALMOLOGY & 14 & 0.568 \\
\hline PHYSIOLOGY & 14 & 0.568 \\
\hline ANTHROPOLOGY & 13 & 0.528 \\
\hline PALEONTOLOGY & 13 & 0.528 \\
\hline ANATOMY MORPHOLOGY & 12 & 0.487 \\
\hline BIOCHEMICAL RESEARCH METHODS & 12 & 0.487 \\
\hline GEOGRAPHY & 12 & 0.487 \\
\hline MICROBIOLOGY & 12 & 0.487 \\
\hline PERIPHERAL VASCULAR DISEASE & 12 & 0.487 \\
\hline PSYCHOLOGY & 12 & 0.487 \\
\hline BIOPHYSICS & 11 & 0.446 \\
\hline GASTROENTEROLOGY HEPATOLOGY & 11 & 0.446 \\
\hline MEDICINE LEGAL & 11 & 0.446 \\
\hline PSYCHOLOGY DEVELOPMENTAL & 11 & 0.446 \\
\hline ENVIRONMENTAL STUDIES & 9 & 0.365 \\
\hline HUMANITIES MULTIDISCIPLINARY & 9 & 0.365 \\
\hline PSYCHOLOGY CLINICAL & 9 & 0.365 \\
\hline SOCIOLOGY & 9 & 0.365 \\
\hline PARASITOLOGY & 8 & 0.325 \\
\hline DEVELOPMENTAL BIOLOGY & 7 & 0.284 \\
\hline GEOCHEMISTRY GEOPHYSICS & 7 & 0.284 \\
\hline GERONTOLOGY & 7 & 0.284 \\
\hline HISTORY PHILOSOPHY OF SCIENCE & 7 & 0.284 \\
\hline SUBSTANCE ABUSE & 7 & 0.284 \\
\hline BEHAVIORAL SCIENCES & 6 & 0.244 \\
\hline COMPUTER SCIENCE INTERDISCIPLINARY APPLICATIONS & 6 & 0.244 \\
\hline TOXICOLOGY & 6 & 0.244 \\
\hline CHEMISTRY ORGANIC & 5 & 0.203 \\
\hline PATHOLOGY & 5 & 0.203 \\
\hline
\end{tabular}




\begin{tabular}{|c|c|c|}
\hline SOCIAL ISSUES & 5 & 0.203 \\
\hline ALLERGY & 4 & 0.162 \\
\hline DERMATOLOGY & 4 & 0.162 \\
\hline INTEGRATIVE COMPLEMENTARY MEDICINE & 4 & 0.162 \\
\hline MYCOLOGY & 4 & 0.162 \\
\hline ORNITHOLOGY & 3 & 0.122 \\
\hline PSYCHOLOGY BIOLOGICAL & 3 & 0.122 \\
\hline SOCIAL SCIENCES BIOMEDICAL & 2 & 0.081 \\
\hline FAMILY STUDIES & 1 & 0.041 \\
\hline PSYCHOLOGY SOCIAL & 1 & 0.041 \\
\hline
\end{tabular}

Refined by: DOCUMENT TYPES: ( ARTICLE OR BOOK CHAPTER OR PROCEEDINGS PAPER OR REVIEW OR MEETING ABSTRACT ) AND [excluding]WEB OF SCIENCE CATEGORIES: ( ENGINEERING MECHANICAL OR COMPUTER SCIENCE THEORY METHODS OR ENGINEERING ENVIRONMENTAL OR METEOROLOGY ATMOSPHERIC SCIENCES OR BUSINESS OR ASTRONOMY ASTROPHYSICS OR AUTOMATION CONTROL SYSTEMS OR ENERGY FUELS OR OPERATIONS RESEARCH MANAGEMENT SCIENCE OR RADIOLOGY NUCLEAR MEDICINE MEDICAL IMAGING OR ENGINEERING MULTIDISCIPLINARY OR PHYSICS MULTIDISCIPLINARY OR CONSTRUCTION BUILDING TECHNOLOGY OR ECONOMICS OR MATHEMATICS INTERDISCIPLINARY APPLICATIONS OR WATER RESOURCES OR ENGINEERING BIOMEDICAL OR INSTRUMENTS INSTRUMENTATION OR PHYSICS FLUIDS PLASMAS OR MATHEMATICS APPLIED OR ENGINEERING ELECTRICAL ELECTRONIC OR MATERIALS SCIENCE MULTIDISCIPLINARY OR COMPUTER SCIENCE INFORMATION SYSTEMS OR PHYSICS MATHEMATICAL OR SOIL SCIENCE OR ENGINEERING INDUSTRIAL OR ENGINEERING CIVIL OR PHYSICS APPLIED OR MECHANICS OR SURGERY OR EDUCATION EDUCATIONAL RESEARCH OR OPTICS OR PUBLIC ENVIRONMENTAL OCCUPATIONAL HEALTH OR CHEMISTRY PHYSICAL OR STATISTICS PROBABILITY OR NANOSCIENCE NANOTECHNOLOGY OR CHEMISTRY APPLIED OR PHYSICS ATOMIC MOLECULAR CHEMICAL OR TELECOMMUNICATIONS OR ENGINEERING CHEMICAL OR MARINE FRESHWATER BIOLOGY OR THERMODYNAMICS OR COMPUTER SCIENCE ARTIFICIAL INTELLIGENCE OR METALLURGY METALLURGICAL ENGINEERING OR OCEANOGRAPHY OR CHEMISTRY ANALYTICAL OR POLYMER SCIENCE OR COMPUTER SCIENCE SOFTWARE ENGINEERING OR MANAGEMENT OR GEOSCIENCES MULTIDISCIPLINARY OR IMAGING SCIENCE PHOTOGRAPHIC TECHNOLOGY OR BUSINESS FINANCE OR PHYSICS CONDENSED MATTER OR SPECTROSCOPY OR AGRICULTURAL ENGINEERING ) AND [excluding] WEB OF SCIENCE CATEGORIES: ( MATERIALS SCIENCE PAPER WOOD OR AREA STUDIES OR COMMUNICATION OR MATHEMATICS OR MICROSCOPY OR OBSTETRICS GYNECOLOGY OR ENGINEERING AEROSPACE OR GERIATRICS GERONTOLOGY OR GREEN SUSTAINABLE SCIENCE TECHNOLOGY OR INFORMATION SCIENCE LIBRARY SCIENCE OR LANGUAGE LINGUISTICS OR LAW OR MINING MINERAL PROCESSING OR AGRICULTURAL ECONOMICS POLICY OR DENTISTRY ORAL SURGERY MEDICINE OR ELECTROCHEMISTRY OR HEMATOLOGY OR HOSPITALITY LEISURE SPORT TOURISM OR LINGUISTICS OR MATERIALS SCIENCE TEXTILES OR ORTHOPEDICS OR RESPIRATORY SYSTEM OR UROLOGY NEPHROLOGY OR MINERALOGY OR NUCLEAR SCIENCE TECHNOLOGY OR TRANSPORTATION SCIENCE TECHNOLOGY OR ENGINEERING GEOLOGICAL OR GEOLOGY OR HEALTH CARE SCIENCES SERVICES OR HISTORY OR INTERNATIONAL RELATIONS OR PHYSICS NUCLEAR OR POLITICAL SCIENCE OR PSYCHOLOGY EDUCATIONAL OR CRITICAL CARE MEDICINE OR CRYSTALLOGRAPHY OR FISHERIES OR NURSING OR PHYSICS PARTICLES FIELDS OR REMOTE SENSING OR SPORT SCIENCES OR ACOUSTICS OR ANESTHESIOLOGY OR ARCHAEOLOGY OR ART OR DEVELOPMENT STUDIES OR ETHICS OR MATERIALS SCIENCE CERAMICS OR MATERIALS SCIENCE CHARACTERIZATION TESTING OR MATERIALS SCIENCE COATINGS FILMS OR OTORHINOLARYNGOLOGY OR REHABILITATION OR RHEUMATOLOGY OR SOCIAL WORK OR VIROLOGY OR ANDROLOGY OR AUDIOLOGY SPEECH LANGUAGE PATHOLOGY OR CHEMISTRY INORGANIC NUCLEAR OR CRIMINOLOGY PENOLOGY OR EDUCATION SCIENTIFIC DISCIPLINES OR ENGINEERING MARINE OR INFECTIOUS DISEASES OR LIMNOLOGY OR MATERIALS SCIENCE BIOMATERIALS OR MATERIALS SCIENCE COMPOSITES OR MEDICAL INFORMATICS OR MEDICAL LABORATORY TECHNOLOGY OR PEDIATRICS OR PSYCHOLOGY APPLIED OR REGIONAL URBAN PLANNING OR TRANSPLANTATION OR TRANSPORTATION OR URBAN STUDIES OR WOMEN S STUDIES OR ARCHITECTURE OR COMPUTER SCIENCE HARDWARE ARCHITECTURE OR CULTURAL STUDIES OR ENGINEERING PETROLEUM OR GEOGRAPHY PHYSICAL OR LITERATURE OR MUSIC OR PLANNING DEVELOPMENT OR TROPICAL MEDICINE ) 
QUERY 3: TS=("qualitative trait*" OR "qualitative character*" OR "Mendelian trait*" OR "Mendelian character*" OR "Mendelian disease*")

Results: 3,233

Timespan: All years (1985-2019)

Indexes: SCI-EXPANDED, SSCI, A\&HCI, CPCI-S, CPCI-SSH, ESCI

Bar Graph 5: Query ("qualitative trait*" OR "qualitative character*" OR "Mendelian trait*" OR "Mendelian character*" OR "Mendelian disease*") per year of publication

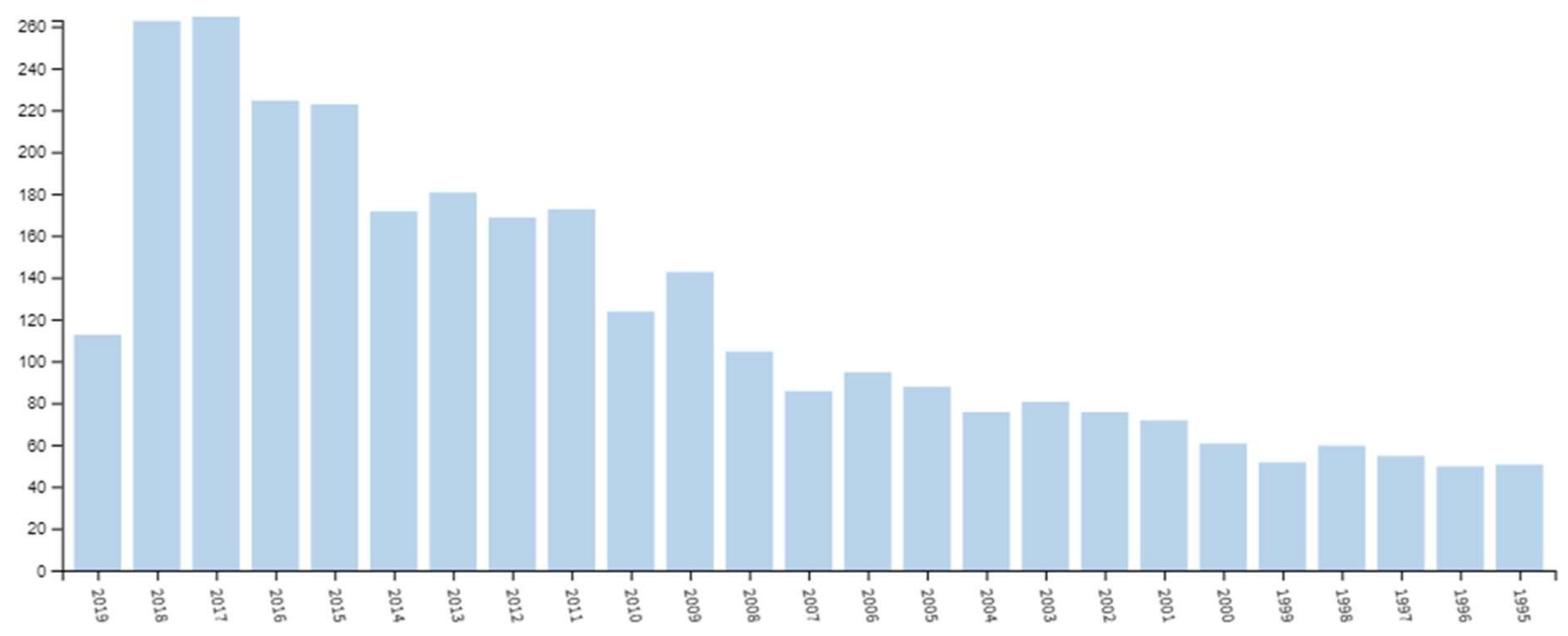

Bar Graph 6: Query ("qualitative trait*” OR "qualitative character*” OR "Mendelian trait*" OR "Mendelian character*" OR "Mendelian disease*") per research area

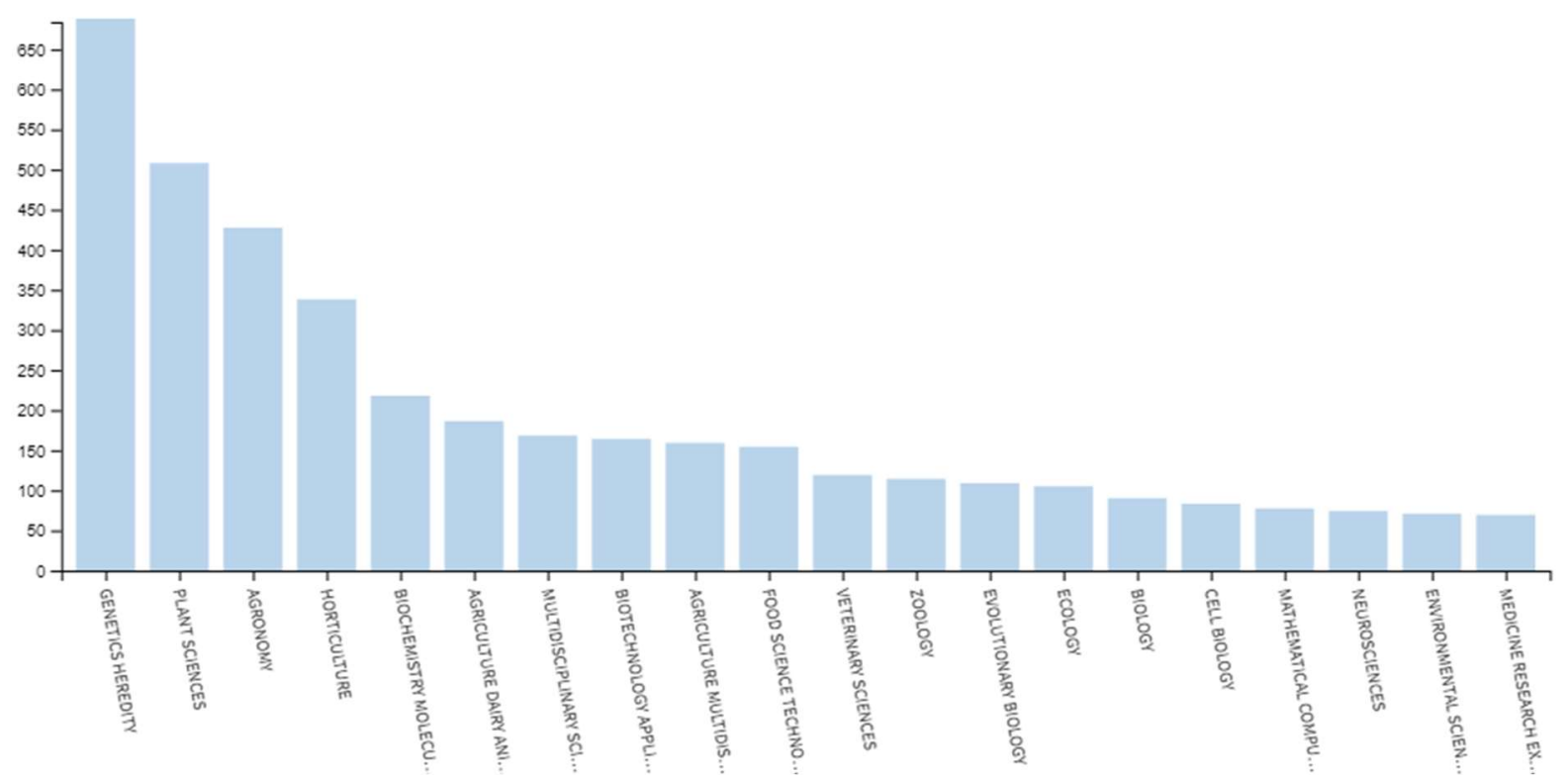




\begin{tabular}{|c|c|c|}
\hline Web of Science Categories & records & $\%$ of 3233 \\
\hline GENETICS HEREDITY & 684 & 21.157 \\
\hline PLANT SCIENCES & 504 & 15.589 \\
\hline AGRONOMY & 423 & 13.084 \\
\hline HORTICULTURE & 334 & 10.331 \\
\hline BIOCHEMISTRY MOLECULAR BIOLOGY & 214 & 6.619 \\
\hline AGRICULTURE DAIRY ANIMAL SCIENCE & 182 & 5.629 \\
\hline MULTIDISCIPLINARY SCIENCES & 164 & 5.073 \\
\hline BIOTECHNOLOGY APPLIED MICROBIOLOGY & 160 & 4.949 \\
\hline AGRICULTURE MULTIDISCIPLINARY & 155 & 4.794 \\
\hline FOOD SCIENCE TECHNOLOGY & 150 & 4.640 \\
\hline VETERINARY SCIENCES & 115 & 3.557 \\
\hline ZOOLOGY & 110 & 3.402 \\
\hline EVOLUTIONARY BIOLOGY & 105 & 3.248 \\
\hline ECOLOGY & 101 & 3.124 \\
\hline BIOLOGY & 86 & 2.660 \\
\hline CELL BIOLOGY & 79 & 2.444 \\
\hline MATHEMATICAL COMPUTATIONAL BIOLOGY & 73 & 2.258 \\
\hline NEUROSCIENCES & 70 & 2.165 \\
\hline ENVIRONMENTAL SCIENCES & 67 & 2.072 \\
\hline MEDICINE RESEARCH EXPERIMENTAL & 65 & 2.011 \\
\hline CLINICAL NEUROLOGY & 59 & 1.825 \\
\hline FORESTRY & 56 & 1.732 \\
\hline CHEMISTRY MULTIDISCIPLINARY & 50 & 1.547 \\
\hline PHARMACOLOGY PHARMACY & 49 & 1.516 \\
\hline CARDIAC CARDIOVASCULAR SYSTEMS & 45 & 1.392 \\
\hline ONCOLOGY & 43 & 1.330 \\
\hline BIOCHEMICAL RESEARCH METHODS & 41 & 1.268 \\
\hline ENDOCRINOLOGY METABOLISM & 38 & 1.175 \\
\hline IMMUNOLOGY & 37 & 1.144 \\
\hline PSYCHIATRY & 35 & 1.083 \\
\hline PERIPHERAL VASCULAR DISEASE & 33 & 1.021 \\
\hline BIODIVERSITY CONSERVATION & 29 & 0.897 \\
\hline NUTRITION DIETETICS & 28 & 0.866 \\
\hline PSYCHOLOGY MULTIDISCIPLINARY & 26 & 0.804 \\
\hline PHILOSOPHY & 25 & 0.773 \\
\hline ENTOMOLOGY & 24 & 0.742 \\
\hline SOCIAL SCIENCES INTERDISCIPLINARY & 22 & 0.680 \\
\hline TOXICOLOGY & 22 & 0.680 \\
\hline ANTHROPOLOGY & 21 & 0.650 \\
\hline PHYSIOLOGY & 21 & 0.650 \\
\hline BIOPHYSICS & 19 & 0.588 \\
\hline GASTROENTEROLOGY HEPATOLOGY & 19 & 0.588 \\
\hline REPRODUCTIVE BIOLOGY & 19 & 0.588 \\
\hline DERMATOLOGY & 18 & 0.557 \\
\hline MICROBIOLOGY & 18 & 0.557 \\
\hline CHEMISTRY MEDICINAL & 17 & 0.526 \\
\hline HEMATOLOGY & 16 & 0.495 \\
\hline PATHOLOGY & 15 & 0.464 \\
\hline DEVELOPMENTAL BIOLOGY & 14 & 0.433 \\
\hline PALEONTOLOGY & 13 & 0.402 \\
\hline ANATOMY MORPHOLOGY & 12 & 0.371 \\
\hline COMPUTER SCIENCE INTERDISCIPLINARY APPLICATIONS & 9 & 0.278 \\
\hline HUMANITIES MULTIDISCIPLINARY & 9 & 0.278 \\
\hline BEHAVIORAL SCIENCES & 8 & 0.247 \\
\hline HISTORY PHILOSOPHY OF SCIENCE & 7 & 0.217 \\
\hline SUBSTANCE ABUSE & 6 & 0.186 \\
\hline CHEMISTRY ORGANIC & 5 & 0.155 \\
\hline PSYCHOLOGY DEVELOPMENTAL & 5 & 0.155 \\
\hline RESPIRATORY SYSTEM & 5 & 0.155 \\
\hline ORNITHOLOGY & 4 & 0.124 \\
\hline PSYCHOLOGY & 4 & 0.124 \\
\hline INFECTIOUS DISEASES & 3 & 0.093 \\
\hline MEDICAL INFORMATICS & 3 & 0.093 \\
\hline VIROLOGY & 3 & 0.093 \\
\hline CELL TISSUE ENGINEERING & 1 & 0.031 \\
\hline FAMILY STUDIES & 1 & 0.031 \\
\hline PSYCHOLOGY BIOLOGICAL & 1 & 0.031 \\
\hline SOCIAL SCIENCES BIOMEDICAL & 1 & 0.031 \\
\hline
\end{tabular}


Refined by: DOCUMENT TYPES: ( ARTICLE OR PROCEEDINGS PAPER OR BOOK CHAPTER OR REVIEW OR MEETING ABSTRACT ) AND [excluding]WEB OF SCIENCE CATEGORIES: ( MANAGEMENT OR GEOSCIENCES MULTIDISCIPLINARY OR PHYSICS ATOMIC MOLECULAR CHEMICAL OR BUSINESS FINANCE OR METALLURGY METALLURGICAL ENGINEERING OR AGRICULTURAL ENGINEERING OR COMPUTER SCIENCE THEORY METHODS OR ENGINEERING BIOMEDICAL OR ENGINEERING MECHANICAL OR MEDICINE GENERAL INTERNAL OR PHYSICS CONDENSED MATTER OR STATISTICS PROBABILITY OR PSYCHOLOGY EXPERIMENTAL OR ENGINEERING ENVIRONMENTAL OR SURGERY OR BUSINESS OR METEOROLOGY ATMOSPHERIC SCIENCES OR RADIOLOGY NUCLEAR MEDICINE MEDICAL IMAGING OR AUTOMATION CONTROL SYSTEMS OR ASTRONOMY ASTROPHYSICS OR ECONOMICS OR ENERGY FUELS OR MATHEMATICS INTERDISCIPLINARY APPLICATIONS OR COMPUTER SCIENCE INFORMATION SYSTEMS OR OPERATIONS RESEARCH MANAGEMENT SCIENCE OR ENGINEERING ELECTRICAL ELECTRONIC OR OPHTHALMOLOGY OR MATERIALS SCIENCE MULTIDISCIPLINARY OR ENGINEERING MULTIDISCIPLINARY OR CONSTRUCTION BUILDING TECHNOLOGY OR PHYSICS MULTIDISCIPLINARY OR PHYSICS FLUIDS PLASMAS OR MATHEMATICS APPLIED OR PHYSICS MATHEMATICAL OR PUBLIC ENVIRONMENTAL OCCUPATIONAL HEALTH OR ENVIRONMENTAL STUDIES OR WATER RESOURCES OR PHYSICS APPLIED OR INSTRUMENTS INSTRUMENTATION OR ENGINEERING INDUSTRIAL OR EDUCATION EDUCATIONAL RESEARCH OR SOIL SCIENCE OR OBSTETRICS GYNECOLOGY OR CHEMISTRY PHYSICAL OR ENGINEERING CIVIL OR PEDIATRICS OR CHEMISTRY APPLIED OR MECHANICS OR ENGINEERING CHEMICAL OR OPTICS OR CHEMISTRY ANALYTICAL OR MARINE FRESHWATER BIOLOGY OR COMPUTER SCIENCE ARTIFICIAL INTELLIGENCE ) AND [excluding] WEB OF SCIENCE CATEGORIES: ( GEOGRAPHY OR POLYMER SCIENCE OR UROLOGY NEPHROLOGY OR SOCIOLOGY OR GERONTOLOGY OR MATERIALS SCIENCE PAPER WOOD OR MEDICINE LEGAL OR RHEUMATOLOGY OR PSYCHOLOGY CLINICAL OR DENTISTRY ORAL SURGERY MEDICINE OR GEOCHEMISTRY GEOPHYSICS OR ALLERGY OR AREA STUDIES OR COMMUNICATION OR GERIATRICS GERONTOLOGY OR MATHEMATICS OR MEDICAL LABORATORY TECHNOLOGY OR MICROSCOPY OR PARASITOLOGY OR ENGINEERING AEROSPACE OR INFORMATION SCIENCE LIBRARY SCIENCE OR LANGUAGE LINGUISTICS OR LAW OR MINING MINERAL PROCESSING OR ORTHOPEDICS OR AGRICULTURAL ECONOMICS POLICY OR ELECTROCHEMISTRY OR MATERIALS SCIENCE TEXTILES OR NUCLEAR SCIENCE TECHNOLOGY OR OCEANOGRAPHY OR REMOTE SENSING OR COMPUTER SCIENCE SOFTWARE ENGINEERING OR HOSPITALITY LEISURE SPORT TOURISM OR MINERALOGY OR SOCIAL ISSUES OR TRANSPORTATION SCIENCE TECHNOLOGY OR EDUCATION SCIENTIFIC DISCIPLINES OR ENGINEERING GEOLOGICAL OR GEOLOGY OR HEALTH CARE SCIENCES SERVICES OR HISTORY OR IMAGING SCIENCE PHOTOGRAPHIC TECHNOLOGY OR INTERNATIONAL RELATIONS OR LINGUISTICS OR MATERIALS SCIENCE CHARACTERIZATION TESTING OR OTORHINOLARYNGOLOGY OR PHYSICS NUCLEAR OR POLITICAL SCIENCE OR PSYCHOLOGY SOCIAL OR CRITICAL CARE MEDICINE OR CRYSTALLOGRAPHY OR ETHICS OR FISHERIES OR INTEGRATIVE COMPLEMENTARY MEDICINE OR LIMNOLOGY OR MYCOLOGY OR NURSING OR PHYSICS PARTICLES FIELDS OR PSYCHOLOGY EDUCATIONAL OR THERMODYNAMICS OR ACOUSTICS OR ANESTHESIOLOGY OR ARCHAEOLOGY OR ART OR DEVELOPMENT STUDIES OR GREEN SUSTAINABLE SCIENCE TECHNOLOGY OR HEALTH POLICY SERVICES OR MATERIALS SCIENCE BIOMATERIALS OR MATERIALS SCIENCE CERAMICS OR MATERIALS SCIENCE COATINGS FILMS OR MATERIALS SCIENCE COMPOSITES OR REHABILITATION OR SOCIAL WORK OR SPORT SCIENCES OR ANDROLOGY OR AUDIOLOGY SPEECH LANGUAGE PATHOLOGY OR CHEMISTRY INORGANIC NUCLEAR OR CRIMINOLOGY PENOLOGY OR ENGINEERING MARINE OR PSYCHOLOGY APPLIED OR REGIONAL URBAN PLANNING OR SPECTROSCOPY OR TELECOMMUNICATIONS OR TRANSPLANTATION OR TRANSPORTATION OR WOMEN S STUDIES OR ARCHITECTURE OR COMPUTER SCIENCE HARDWARE ARCHITECTURE OR CULTURAL STUDIES OR ENGINEERING PETROLEUM OR GEOGRAPHY PHYSICAL OR LITERATURE OR MEDICAL ETHICS OR MUSIC OR NANOSCIENCE NANOTECHNOLOGY OR PLANNING DEVELOPMENT OR SOCIAL SCIENCES MATHEMATICAL METHODS OR TROPICAL MEDICINE OR URBAN STUDIES) 
QUERY 4: TS=("quantitative trait*" AND "qualitative trait*" OR "quantitative character*" AND "qualitative character*")

Results: 418

Timespan: All years (1985-2019)

Indexes: SCI-EXPANDED, SSCI, A\&HCI, CPCI-S, CPCI-SSH, ESCI

Bar Graph 7: Query ("quantitative trait*" AND "qualitative trait*" OR "quantitative character*" AND "qualitative character*") per year of publication

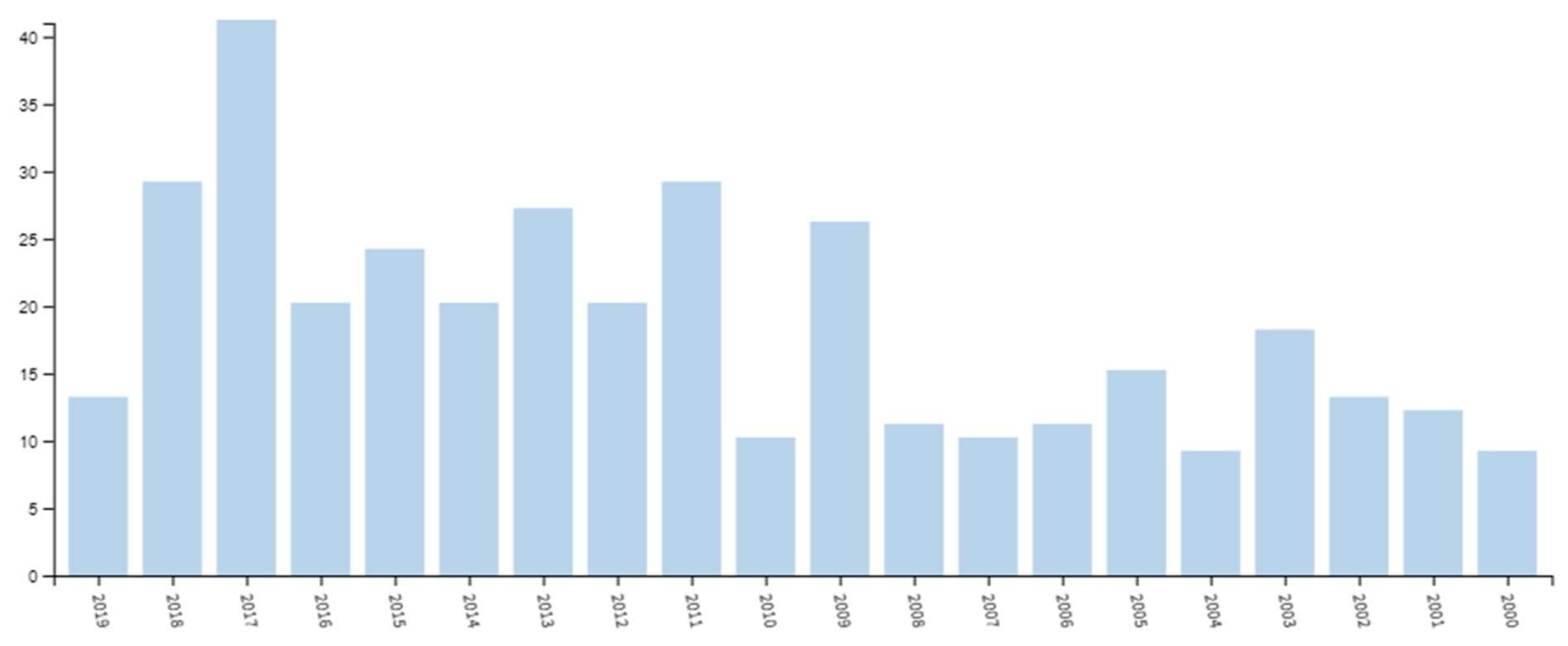

Bar Graph 8: Query ("quantitative trait*" AND "qualitative trait*" OR "quantitative character*" AND "qualitative character*") per research area

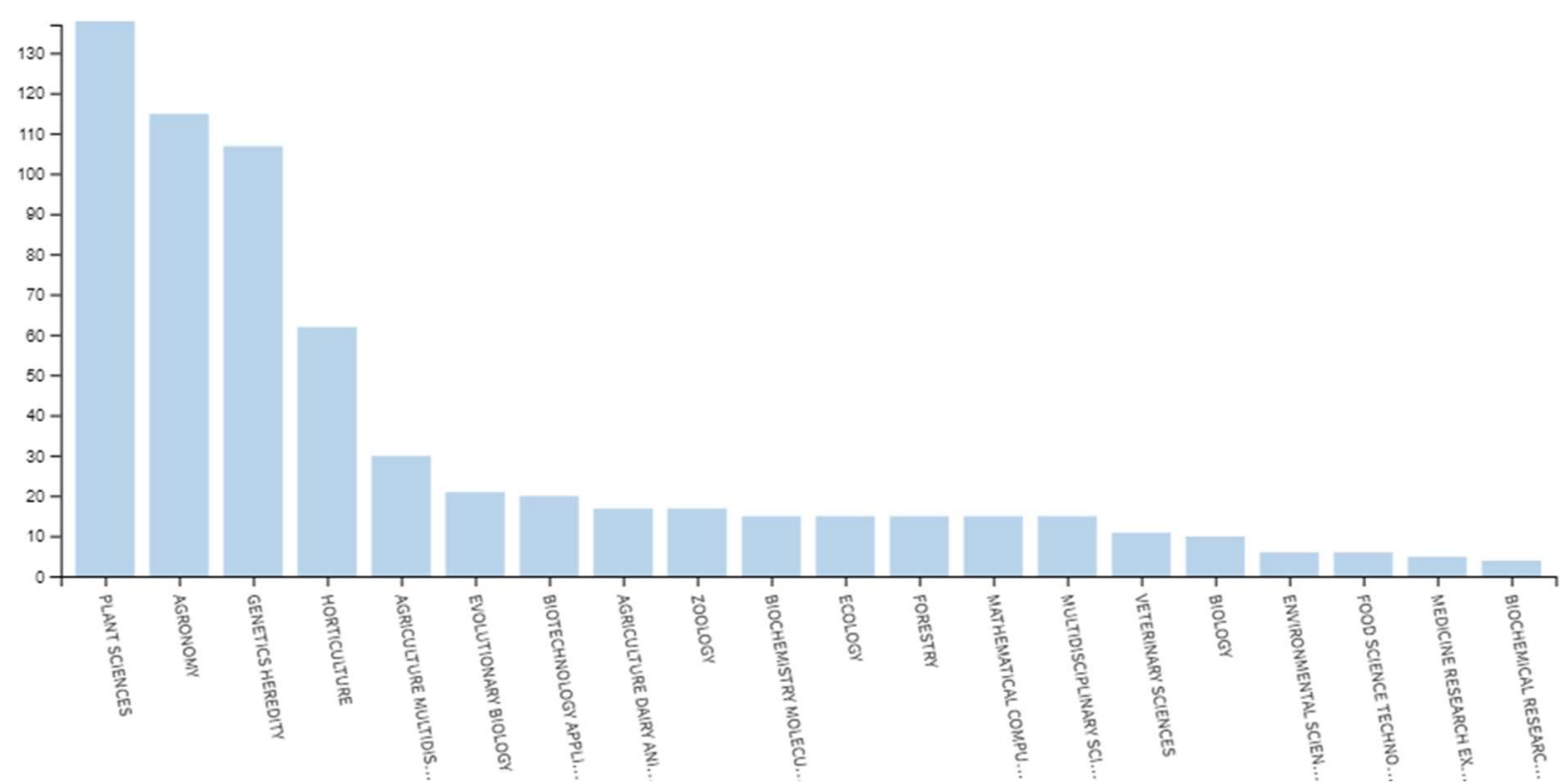




\begin{tabular}{|c|c|c|}
\hline Web of Science Categories & records & $\%$ of 418 \\
\hline PLANT SCIENCES & 137 & 32.775 \\
\hline AGRONOMY & 114 & 27.273 \\
\hline GENETICS HEREDITY & 106 & 25.359 \\
\hline HORTICULTURE & 61 & 14.593 \\
\hline AGRICULTURE MULTIDISCIPLINARY & 29 & 6.938 \\
\hline EVOLUTIONARY BIOLOGY & 20 & 4.785 \\
\hline BIOTECHNOLOGY APPLIED MICROBIOLOGY & 19 & 4.545 \\
\hline AGRICULTURE DAIRY ANIMAL SCIENCE & 16 & 3.828 \\
\hline ZOOLOGY & 16 & 3.828 \\
\hline BIOCHEMISTRY MOLECULAR BIOLOGY & 14 & 3.349 \\
\hline ECOLOGY & 14 & 3.349 \\
\hline FORESTRY & 14 & 3.349 \\
\hline MATHEMATICAL COMPUTATIONAL BIOLOGY & 14 & 3.349 \\
\hline MULTIDISCIPLINARY SCIENCES & 14 & 3.349 \\
\hline VETERINARY SCIENCES & 10 & 2.392 \\
\hline BIOLOGY & 9 & 2.153 \\
\hline ENVIRONMENTAL SCIENCES & 5 & 1.196 \\
\hline FOOD SCIENCE TECHNOLOGY & 5 & 1.196 \\
\hline MEDICINE RESEARCH EXPERIMENTAL & 4 & 0.957 \\
\hline BIOCHEMICAL RESEARCH METHODS & 3 & 0.718 \\
\hline IMMUNOLOGY & 3 & 0.718 \\
\hline PHARMACOLOGY PHARMACY & 3 & 0.718 \\
\hline BIODIVERSITY CONSERVATION & 2 & 0.478 \\
\hline BIOPHYSICS & 2 & 0.478 \\
\hline CHEMISTRY MULTIDISCIPLINARY & 2 & 0.478 \\
\hline DEVELOPMENTAL BIOLOGY & 2 & 0.478 \\
\hline ENDOCRINOLOGY METABOLISM & 2 & 0.478 \\
\hline PERIPHERAL VASCULAR DISEASE & 2 & 0.478 \\
\hline SUBSTANCE ABUSE & 2 & 0.478 \\
\hline ALLERGY & 1 & 0.239 \\
\hline ANTHROPOLOGY & 1 & 0.239 \\
\hline CARDIAC CARDIOVASCULAR SYSTEMS & 1 & 0.239 \\
\hline CELL BIOLOGY & 1 & 0.239 \\
\hline CHEMISTRY MEDICINAL & 1 & 0.239 \\
\hline COMPUTER SCIENCE INTERDISCIPLINARY APPLICATIONS & 1 & 0.239 \\
\hline DERMATOLOGY & 1 & 0.239 \\
\hline ENTOMOLOGY & 1 & 0.239 \\
\hline GASTROENTEROLOGY HEPATOLOGY & 1 & 0.239 \\
\hline INTEGRATIVE COMPLEMENTARY MEDICINE & 1 & 0.239 \\
\hline MYCOLOGY & 1 & 0.239 \\
\hline NEUROSCIENCES & 1 & 0.239 \\
\hline NUTRITION DIETETICS & 1 & 0.239 \\
\hline PALEONTOLOGY & 1 & 0.239 \\
\hline PEDIATRICS & 1 & 0.239 \\
\hline PSYCHOLOGY SOCIAL & 1 & 0.239 \\
\hline REPRODUCTIVE BIOLOGY & 1 & 0.239 \\
\hline
\end{tabular}

Refined by: DOCUMENT TYPES: ( ARTICLE OR PROCEEDINGS PAPER OR REVIEW ) AND [excluding] WEB OF SCIENCE CATEGORIES: ( AUDIOLOGY SPEECH LANGUAGE PATHOLOGY OR INSTRUMENTS INSTRUMENTATION OR AUTOMATION CONTROL SYSTEMS OR MICROSCOPY OR BUSINESS FINANCE OR ORTHOPEDICS OR ACOUSTICS OR COMPUTER SCIENCE INFORMATION SYSTEMS OR CONSTRUCTION BUILDING TECHNOLOGY OR CRITICAL CARE MEDICINE OR COMPUTER SCIENCE THEORY METHODS OR EDUCATION EDUCATIONAL RESEARCH OR ENERGY FUELS OR ECONOMICS OR ENGINEERING BIOMEDICAL OR ELECTROCHEMISTRY OR ENGINEERING CHEMICAL OR ENGINEERING CIVIL OR ENGINEERING MECHANICAL OR ENGINEERING ENVIRONMENTAL OR GEOLOGY OR ENGINEERING MANUFACTURING OR GEOSCIENCES MULTIDISCIPLINARY OR ENGINEERING MULTIDISCIPLINARY OR STATISTICS PROBABILITY OR MATHEMATICS APPLIED OR MATERIALS SCIENCE MULTIDISCIPLINARY OR ENVIRONMENTAL STUDIES OR AGRICULTURAL ENGINEERING OR PHYSICS CONDENSED MATTER OR HOSPITALITY LEISURE SPORT TOURISM OR PUBLIC ADMINISTRATION OR IMAGING SCIENCE PHOTOGRAPHIC TECHNOLOGY OR CHEMISTRY PHYSICAL OR SOCIOLOGY OR LANGUAGE LINGUISTICS OR MARINE FRESHWATER BIOLOGY OR SOIL SCIENCE OR LINGUISTICS OR SPECTROSCOPY OR MANAGEMENT OR OPHTHALMOLOGY OR MATERIALS SCIENCE COATINGS FILMS OR PHYSICS APPLIED OR WATER RESOURCES OR MATHEMATICS INTERDISCIPLINARY APPLICATIONS OR AGRICULTURAL ECONOMICS POLICY OR MEDICINE GENERAL INTERNAL OR CHEMISTRY ANALYTICAL OR MINING MINERAL PROCESSING OR CHEMISTRY APPLIED OR ARCHAEOLOGY OR ENGINEERING ELECTRICAL ELECTRONIC OR AREA STUDIES OR FISHERIES ) AND [excluding] WEB OF SCIENCE CATEGORIES: ( OPTICS OR PARASITOLOGY OR PUBLIC ENVIRONMENTAL OCCUPATIONAL HEALTH OR RADIOLOGY NUCLEAR MEDICINE MEDICAL IMAGING OR TRANSPLANTATION ) 